\title{
Hydrogeochemical Assessment of Groundwater and Suitability Analysis for Domestic and Agricultural Utility in Southern Punjab, Pakistan
}

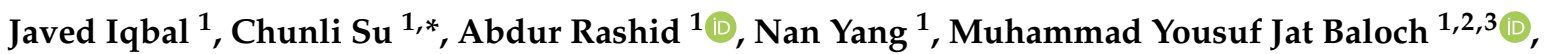 \\ Shakeel Ahmed Talpur ${ }^{1}$, Zahid Ullah ${ }^{1}$, Gohar Rahman ${ }^{4}$, Naveed Ur Rahman ${ }^{5}$, Earjh ${ }^{6}$ and \\ Meer Muhammad Sajjad 7,8
}

check for updates

Citation: Iqbal, J.; Su, C.; Rashid, A.; Yang, N.; Baloch, M.Y.J.; Talpur, S.A.; Ullah, Z.; Rahman, G.; Rahman, N.U.; Earjh; et al. Hydrogeochemical

Assessment of Groundwater and Suitability Analysis for Domestic and Agricultural Utility in Southern Punjab, Pakistan. Water 2021, 13, 3589 https://doi.org/10.3390/w13243589

Academic Editor:

Adriana Bruggeman

Received: 3 November 2021

Accepted: 10 December 2021

Published: 14 December 2021

Publisher's Note: MDPI stays neutral with regard to jurisdictional claims in published maps and institutional affiliations.

Copyright: (c) 2021 by the authors. Licensee MDPI, Basel, Switzerland. This article is an open access article distributed under the terms and conditions of the Creative Commons Attribution (CC BY) license (https:/ / creativecommons.org/licenses/by/ $4.0 /)$.
1 School of Environmental Studies, China University of Geosciences Wuhan, 388 Lumo Road, Wuhan 430074, China; javediqbal@cug.edu.cn (J.I.); abdur.rashid@bs.qau.edu.pk (A.R.); 20151002705@cug.edu.cn (N.Y.); engr.yousuf@yahoo.com (M.Y.J.B.); talpurshakill@yahoo.com (S.A.T.); 2201890048@cug.edu.cn (Z.U.)

2 Key Laboratory of Groundwater Resources and Environment, Ministry of Education, Jilin University, Changchun 130021, China

3 College of New Energy and Environment, Jilin University, Changchun 130021, China

4 College of Construction Engineering, Jilin University, Changchun 130026, China; geologist.gohar11@yahoo.com

5 College of Geosciences, China University of Petroleum, Beijing 102200, China; naveedk91@yahoo.com

6 School of Resources and Environmental Engineering, Wuhan University of Technology, Wuhan 430070, China; earjh@whut.edu.cn

7 Institute of Geographic Sciences and Natural Resources Research (IGSNRR), Chinese Academy of Sciences, Beijing 100101, China; Meersajjad@igsnrr.ac.cn

8 University of Chinese Academy of Sciences (UCAS), Beijing 101408, China

* Correspondence: chl.su@cug.edu.cn

\begin{abstract}
Groundwater is a critical water supply for safe drinking water, agriculture, and industry worldwide. In the Khanewal district of Punjab, Pakistan, groundwater has severely deteriorated during the last few decades due to environmental changes and anthropogenic activities. Therefore, 68 groundwater samples were collected and analyzed for their main ions and trace elements to investigate the suitability of groundwater sources for drinking and agricultural purposes. Principal component analysis (PCA) and cluster analysis (CA) were employed to determine the major factors influencing groundwater quality. To assess the groundwater's appropriateness for drinking and irrigation, drinking and agricultural indices were used. The $\mathrm{pH}$ of the groundwater samples ranged from 6.9 to 9.2 , indicating that the aquifers were slightly acidic to alkaline. The major cations were distributed as follows: $\mathrm{Na}^{+}>\mathrm{Ca}^{2+}>\mathrm{Mg}^{2+}>\mathrm{K}^{+}$. Meanwhile, the anions are distributed as follows: $\mathrm{HCO}_{3}{ }^{-}>\mathrm{SO}_{4}{ }^{2-}>\mathrm{Cl}^{-}>\mathrm{F}^{-}$. The main hydrochemical facies were identified as a mixed type; however, a mixed magnesium, calcium, and chloride pattern was observed. The reverse ion exchange process helps in exchanging $\mathrm{Na}^{+}$with $\mathrm{Ca}^{2+}$ and $\mathrm{Mg}^{2+}$ ions in the groundwater system. Rock weathering processes, such as the dissolution of calcite, dolomite, and gypsum minerals, dominated the groundwater hydrochemistry. According to the Weight Arithmetic Water Quality Index (WAWQI), 50\% of the water samples were unsafe for drinking. The Wilcox diagram, USSL diagram, and some other agricultural indices resulted in around $32 \%$ of the groundwater samples being unsuitable for irrigation purposes. The Khanewal's groundwater quality was vulnerable due to geology and the influence of anthropogenic activities. For groundwater sustainability in Khanewal, management strategies and policies are required.
\end{abstract}

Keywords: groundwater; hydrogeochemical processes; Water Quality Index; correlation analysis; Khanewal district 


\section{Introduction}

Groundwater is the principal water supply source for household, agricultural, and industrial purposes in many countries [1]. Approximately one third of the world's population relies on groundwater for drinking [2]. In some arid and semi-arid regions, groundwater is the only source of drinking water [3,4]. Groundwater resources have been experiencing increasing problems in recent years, including quality issues and the depletion of freshwater resources, attributed to both anthropogenic and geogenic factors [5,6]. N-fertilizer, manure applications, and pesticides have enhanced crop yields, but they have a negative impact on the groundwater quality [7].

Recharge sources, geological structure, hydrological setting, the mineralogy of the watersheds and aquifers, and water-rock interaction, including mineral dissolution, ion exchange, redox, and anthropogenic activities, are all potential factors that affect groundwater quality [6]. Water quality is just as important as its quantity when meeting basic human needs, since a shortage of water and sanitation creates a slew of public health issues [8,9]. Contamination and overexploitation are responsible for the poor quality of groundwater. Understanding the significant factors influencing the qualitative and hydrochemical properties of accessible groundwater is thus crucial for maintaining a sufficient supply for various purposes $[10,11]$. Analysis and plots can be alternative to the isotopic studies for identifying the major factors that characterize the hydrogeochemical mechanism, such as multivariate analysis, USSL, silicate weathering, Gibbs plots and saturation indices. This analysis was carried out in some previous and recent studies $[4,8,12,13]$.

The groundwater quality and hydrochemical features within a region are the basis for analyzing the utilization and availability of regional water resources in recent years [14]. Many hydrochemical components play an essential role in human health [15]. As a result, a detailed understanding of the hydrogeochemical processes is required to evaluate the suitability of groundwater for drinking, agriculture, and other applications. Pakistan is a water-stressed country. In the last few decades, both surface and groundwater availability have declined substantially in the surrounding regions of Pakistan [16-18], while the demand for domestic groundwater grew from 5.20 million acres to 9.70 million acres. The significant rise in groundwater quality problems is due to over-exploitation in many areas of Pakistan. Groundwater with elevated arsenic and fluoride concentrations is a serious health issue, while the research on the health effects is still limited. Multiple causes have enhanced Pakistan's groundwater vulnerability in recent decades. TDS levels of 400-20,000 ppm have been reported in entrapped severely mineralized groundwater [19]. The groundwater in Sindh province (Tharparker, Nagarparker, and Umarkot) is polluted with arsenic, resulting in skin injuries on major body parts (arms, face, and feet), rough skin with black dots from dermal and oral contact, and dental and skeletal fluorosis from arsenic- and fluoride-contaminated water [20]. Arsenic and chromium concentrations were significantly higher in the groundwater in Lahore, Muzaffargarh, and Mailsi [21]. As a result of the high fluoride concentration in the groundwater, bone softening and deformation problems have been identified in some areas of Punjab province. Furthermore, high fluoride levels in the groundwater have been reported in Lahore city [22]. In different parts of the world, several hydrogeochemical methods have been used to assess the suitability of groundwater for drinking and agricultural purposes. These methods have recommended various measures to increase water quality [23].

The purpose of this study is to determine the hydrochemistry and suitability of groundwater in the Khanewal district for drinking and irrigation. This study will help us better understand the hydrogeochemical processes that cause ions to form in groundwater, as well as the factors that influence the groundwater quality in the area.

\section{Study Area}

Khanewal is a district of Punjab province in Pakistan situated in the lower Bari of the river Doab between the Sutlej and Ravi rivers (from $29^{\circ} 52^{\prime} 03^{\prime \prime} \mathrm{N}$ to $30^{\circ} 44^{\prime} 30^{\prime \prime} \mathrm{N}$ and from $71^{\circ} 32^{\prime} 19^{\prime \prime} \mathrm{E}$ to $72^{\circ} 28^{\prime} 31^{\prime \prime} \mathrm{E}$ ) with an altitude of $128 \mathrm{~m}$, as shown in Figure 1. According to 
the Pakistani census of 1998, the district had 2,068,490 people, with $17.42 \%$ of them living in urban areas [12]. Four seasons-summer, winter, autumn, and spring-make up the region's climate. The temperature ranges from $21^{\circ} \mathrm{C}$ to $51{ }^{\circ} \mathrm{C}$ during the summer season and from $1{ }^{\circ} \mathrm{C}$ to $27^{\circ} \mathrm{C}$ during the winter season [12]. Khanewal is $134 \mathrm{~m}$ above sea level and has a desert climate, with annual precipitation of about $166 \mathrm{~mm}$. Furthermore, the Köppen-Geiger climate classification classifies the area's climate as BWh.

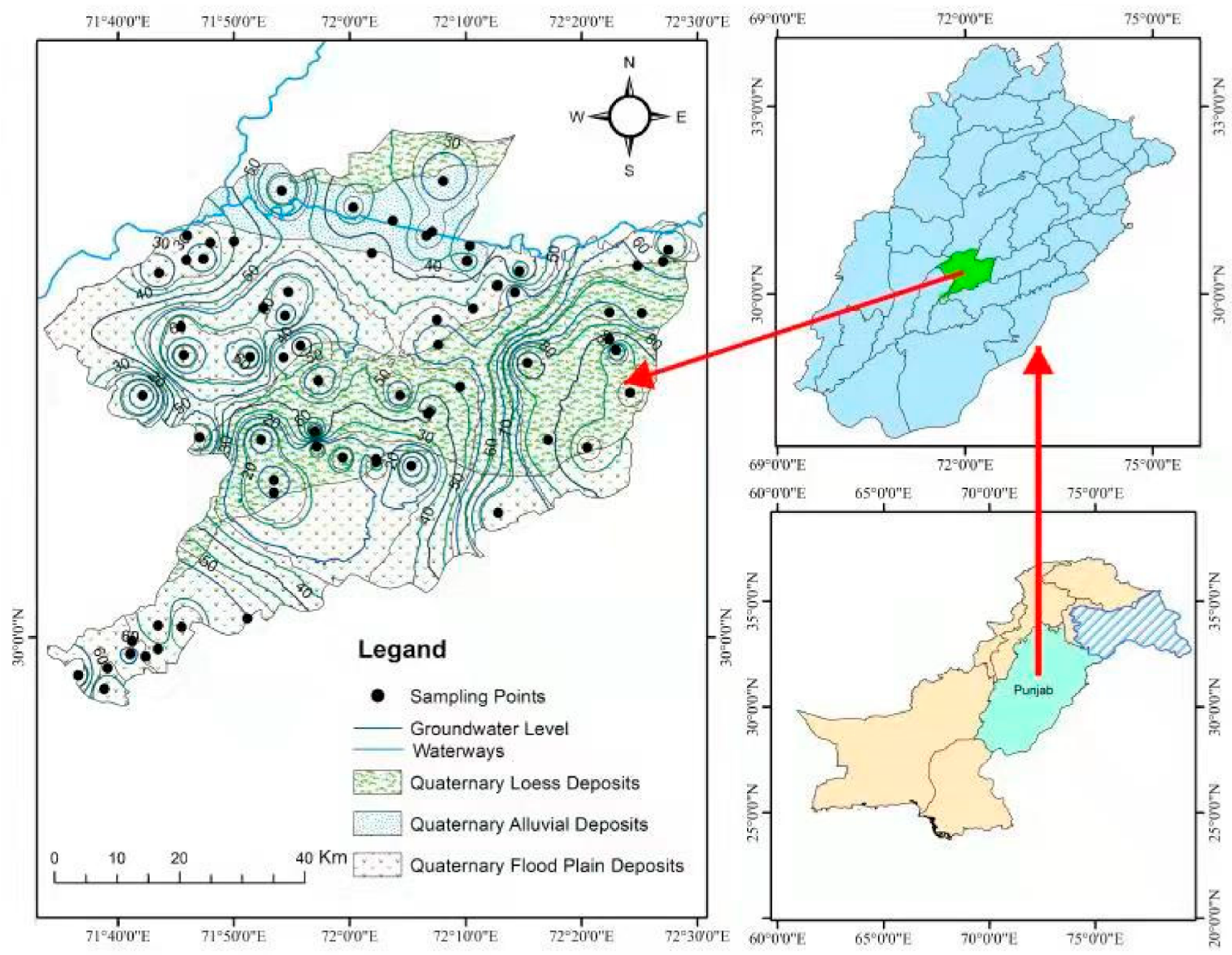

Figure 1. Groundwater sampling points and geological formation of Khanewal district.

\section{Geology and Hydrogeology of the Study Area}

Khanewal is located in the upper Indus plains, and the river in the Khanewal district has significant impact on the basis of the physical qualities in the region. The area's geology is characterized by quaternary loess deposits, quaternary flood plain deposits, and quaternary flood plain deposits (Figure 1). Silt and sand make up the loess deposits. The silt concentration, on the other hand, is estimated to be $60-90 \%$. Loess is wind-blown sediment that preserves a complete record of interglacial glacial cycles on land. Loess ranges in thickness from a few centimeters to more than $91 \mathrm{~m}$. Khanewal loess deposits are heterogeneous sediments that contain buried soils. On the other hand, the quaternary loess deposits are made up of mica, feldspars, quartz, and calcium carbonate. The alluvium overlies semi-consolidated Tertiary rocks or Precambrian age metamorphic igneous rocks. The recent Pleistocene alluvial complex contains unconsolidated silt, sand with gravel, and minor clay. These sediments from the Ravi River and its tributaries make up the soils. The alluvial deposit thickness along major streams ranges up to $30.48 \mathrm{~m}$ and probably averages $12.192 \mathrm{~m}$. Along minor streams, the thickness ranges up to $13.716 \mathrm{~m}$ and probably averages $6.096 \mathrm{~m} \mathrm{[12]}$. The individual stratum's vertical and horizontal continuity is limited in diverse alluvial deposits. The soil is primarily reddish brown to grayish brown in color, 
medium-textured, and contains a lot of fine to very fine sand and very small amounts of clay and gravel [24]. The majority of the alluvial complex comprises fine to medium sand, silt, and clay. In silty or clayey sand, siltstone and mudstone pebbles can be found. The alluvial deposits form a unified, highly transmissive non-artesian aquifer despite their heterogeneity. For the most part, the transmissivity ranges from 954 to $4263 \mathrm{~m}^{3} /$ day $/ \mathrm{m}$ [25]. Above 300 feet, the strata are compacted but exceedingly productive. The water table depth in the area varies between $15 \mathrm{~m}$ and $95 \mathrm{~m}$, with an average of $48.2 \mathrm{~m}$. The water level contour map was created by calculating the individual hydraulic heads (Figure 1).

\section{Materials and Methods}

\subsection{Sampling and Analysis}

In the Khanewal district, groundwater samples $(n=68)$ were collected from different groundwater sources such as wells, boreholes, and hand pumps to investigate the hydrochemical properties and suitability for drinking and agriculture. Groundwater samples were collected in $1.5-\mathrm{L}$ polyethylene bottles and washed with a $10 \% \mathrm{HCl}$ solution. To collect samples from the area, a duplicate sampling technique was used. The basic water quality parameters like $\mathrm{pH}$, water temperature, total dissolved solids, and electric conductivity were measured in situ after sampling. To preserve the groundwater samples, 2-3 drops of $\mathrm{HNO}_{3}$ were added and acidified with a sequence of duplicate samples. The $\mathrm{pH}$, electrical conductivity (EC), and total dissolved solids (TDS) were calculated using a $\mathrm{pH}$ meter and an electrochemical analyzer (Hac 44600-00, Loveland, CO, USA). Significant anions such as nitrate $\left(\mathrm{NO}_{3}-\mathrm{N}\right)$ and sulfate $\left(\mathrm{SO}_{4}{ }^{2-}\right)$ were measured using an ultraviolet-visible (UV-VIS) spectrophotometer (Analytik Jena, Jena, Germany), while the chloride $\left(\mathrm{Cl}^{-}\right)$, total alkalinity, and bicarbonates $\left(\mathrm{HCO}_{3}{ }^{-}\right)$were measured using titration methods. The iron $\left(\mathrm{Fe}^{2+}\right)$ and major cations viz. $\mathrm{Ca}^{2+}, \mathrm{Mg}^{2+}, \mathrm{Na}^{+}$, and $\mathrm{K}^{+}$were analyzed using an atomic absorption spectrophotometer (Varian Spectra AA-240) under standardized operating conditions.

The charge balance error (CBE) was calculated to confirm the authenticity of the water sample analysis. A positive $\mathrm{CBE}$ is associated with higher cation concentrations in these water samples, while a negative CBE is associated with higher anion concentrations [26]. The ionic levels were measured in milliequivalents per liter (meq/L) in this study. The $\mathrm{CBE} \%$ for all groundwater samples was within $\pm 5 \%$, indicating that the analytical data were reliable [27].

\subsection{Statistical Analysis}

\subsubsection{Correlation Analysis}

Correlation analysis is a statistical tool for determining how closely two variables are related. Pearson correlation analysis was used to distinguish the link between several water chemical parameters in this study.

\subsubsection{Hierarchical Cluster Analysis}

Hierarchical clustering is a clustering approach that categorizes distinct datasets based on their similarity, obtained by computing the distance between each category's data points and all of the data points. The Euclidean distance was used in this study to compute the distance between various types of data points. Variance analysis was then used to examine the distances between distinct clusters using Ward's linkage approach $[8,28]$. The final result is displayed as a dendrogram. In addition, the number of clusters is governed by the phenom line.

\subsubsection{Principal Component Analysis}

Principal component analysis (PCA) is a popular method for reducing data dimensionality. PCA can keep the majority of the information while reducing the data's dimensionality $[8,29]$. In this study, principal component analysis (PCA) was used to determine whether the hierarchical cluster analysis was reasonable. SPSS Statistics (Version 20.0) has been used to find the PCA. 


\subsection{Hydrochemical Analysis}

\subsubsection{Geochemical Modeling}

The tendency of groundwater to dissolve or precipitate a particular mineral can be determined using saturation indices [30]. In addition, the measurement of the mineral balance is helpful in predicting the dissolved mineral reactivity in water [31]. Saturation indices have been computed using a geochemical simulation program called PHREEQC Interactive (version 3.4).

\subsubsection{Water Type}

A Durov diagram is commonly used to represent the hydrogeochemical type and relative content of main anions and cations in distinct samples, and it can also show some potential geochemical processes that might assist in the understanding and assessment of groundwater quality [32]. The Durov diagram was prepared with the help of Grapher (version 14).

\subsubsection{Groundwater Classification}

The Gibbs diagram is a common tool to determine the relationship between lithology and hydrochemistry in aquifers [8]. According to this diagram, the dissolved hydrochemical compositions are divided into three distinct areas. Both the cation and anion ratios viz. TDS were plotted against $\mathrm{Na}^{+} /\left(\mathrm{Na}^{+}+\mathrm{Ca}^{2+}\right)$ and $\mathrm{Cl}^{-} /\left(\mathrm{Cl}^{-}+\mathrm{HCO}_{3}^{-}\right)$. We used Microsoft Excel 2020 to draw the Gibbs diagram.

\subsubsection{Ion Exchange Processes}

The chloro-alkaline indices (CAI1 and CAI2) were used to analyze the ion exchange reaction [33]. These indices have a significant influence on the chemistry and evolution of water [34]. The CAI1 and CAI2 were calculated using the formulas below:

$$
\begin{gathered}
\mathrm{CAI} 1=\mathrm{Cl}^{-} \frac{\mathrm{Na}^{+}+\mathrm{K}^{+}}{\mathrm{Cl}^{-}} \\
\mathrm{CAI}=\mathrm{Cl}^{-}\left(\mathrm{Na}^{+}+\mathrm{K}^{+}\right) / \mathrm{SO}_{4}^{2-}+\mathrm{HCO}_{3}^{-}+\mathrm{CO}_{3}^{2-}+\mathrm{NO}_{3}^{-}
\end{gathered}
$$

All units are in milliequivalents per liter (meq/L). When both indices had positive values, direct ion exchange occurred (Equation (3)). When CAI1 and CAI2 had negative levels, reverse ion exchange occurred (Equation (4)):

$$
\begin{gathered}
2 \mathrm{Na}+\mathrm{CaX} 2 \mathrm{Ca}+2 \mathrm{NaX} \\
\mathrm{Ca}+2 \mathrm{NaX}+2 \mathrm{Na}+\mathrm{CaX} 2
\end{gathered}
$$

\subsection{Water Quality Analysis for Drinking}

Water Quality Index (WQI)

The weighted arithmetic water quality index (WAWQI) values were calculated to assess the groundwater's suitability for drinking purposes [35]. The WHO (2011) standard for drinking water was used to calculate the WAWQI. The WAWQI was computed by using Equation (5):

$$
\mathrm{WQI}=\sum_{i=1}^{n} S I_{i}-n
$$

\subsection{Groundwater Quality Evaluation for Irrigation}

Understanding the salinity levels of water, which affect the soil structure and agricultural output, is the primary goal of determining the suitability of water for irrigation. To determine the qualities of irrigation water, the following criteria were applied. 


\subsubsection{Sodium Adsorption Ratio}

The primary indicator for the analysis of groundwater irrigation is the sodium adsorption ratio (SAR) [36]. According to the SAR, the sodium hazard in groundwater can be rated as low (SAR10), medium (10-18), moderate (18-26), or very high (SAR > 26), and the formula is given bellow to find the SAR [37]:

$$
\mathrm{SAR}=\frac{\mathrm{Na}^{+}}{\sqrt{\frac{\mathrm{Ca}^{2+}+\mathrm{Mg}^{2+}}{2}}}
$$

\subsubsection{Soluble Sodium Percentage $(\% \mathrm{Na})$}

The sodium percentage $(\mathrm{Na} \%)$ also indicates how suitable the water is for irrigation [38]. As it reacts with the soil, high sodium levels in groundwater are undesirable, resulting in low permeability. In this way, plant growth is also decreased as a result [39].

The formula for its calculation is as follows:

$$
\% \mathrm{Na}=\frac{\mathrm{Na}^{+}}{\mathrm{Na}^{+}+\mathrm{K}^{+}+\mathrm{Ca}^{2+}+\mathrm{Mg}^{2+}} \times 100
$$

\subsubsection{Kelly's Ratio}

Kelly's ratio is a crucial requirement for determining the quality of groundwater used in agriculture [40]:

$$
\mathrm{KR}=\frac{\mathrm{Na}^{+}}{\mathrm{Ca}^{2+}+\mathrm{Mg}^{2+}}
$$

\subsubsection{Magnesium Hazard}

Magnesium hazard analysis is another approach suggested by Szabolcs and Darab for determining the agricultural suitability of groundwater [41]. Soil modification increases as the $\mathrm{Mg}^{2+}$ content relative to $\mathrm{Ca}^{2+}$ grows, allowing clay particles to scatter and causing damage to the soil structure by reducing hydraulic conductivity:

$$
\mathrm{MH}=\frac{\mathrm{Mg}^{2+}}{\mathrm{Ca}^{2+}+\mathrm{Mg}^{2+}} \times 100
$$

\subsubsection{Permeability Index}

The Permeability Index (PI) is a primary factor for assessing water's appropriateness for irrigation, according to [42]. Class 1 ( $>75 \%$, suitable), class 2 (25-75\%, good), and class 3 (less than $25 \%$, unsuitable) are the three classifications for PI:

$$
\mathrm{PI}=\frac{\mathrm{Na}^{+}+\sqrt{\mathrm{HCO}_{3}^{-}}}{\mathrm{Ca}^{2+}+\mathrm{Mg}^{2+}+\mathrm{Na}^{+}} \times 100
$$

Additionally, Grapher (version 14) software was used to create a U.S. salinity laboratory diagram and a Wilcox diagram by linking the sodium absorption ratio and electrical conductivity and the percentage of sodium and electrical conductivity, respectively, to define and analyze the suitability of groundwater for irrigation.

\section{Results and Discussion}

\subsection{Groundwater Quality and Hydrochemical Characteristics}

Table 1 shows the groundwater statistical results compared with the World Health Organization guidelines. The $\mathrm{pH}$ ranged from 6.9 to 9.2 with a mean value of 7.79 , which suggests that the nature of the groundwater was slightly acidic to alkaline. However, 66 groundwater samples with $97 \%$ contributions were within the WHO's recommended guidelines [43]. The $\mathrm{pH}$ value of the groundwater has no direct impact on human health. However, groundwater in an acidic medium $(\mathrm{pH}=6)$ may accelerate heavy metal solubility 
and leaching, whereas a higher $\mathrm{pH}$ is expected to boost calcite mineral precipitation [44]. The alkalinity of the research area was high due to weathering and anthropogenic activity. Bicarbonate, carbonate, and hydroxide are the most well-known alkalinity components. The breakdown of minerals produces these chemicals [45].

Table 1. Statistical physicochemical parameters of groundwater samples $(n=68)$ collected from the Khanewal district.

\begin{tabular}{|c|c|c|c|c|c|c|c|}
\hline Parameters & Minimum & Maximum & Mean & $\begin{array}{c}\text { Standard } \\
\text { Deviation }\end{array}$ & $\begin{array}{c}\text { WHO } \\
\text { Standards }\end{array}$ & NSBL * & NSBL \% \\
\hline Turbidity (NTU) & 0 & 7 & 2.52 & 1.66 & 5 & 3 & 4.41 \\
\hline $\mathrm{pH}$ & 6.96 & 9.2 & 7.79 & 0.36 & $6.5-8.5$ & 2 & 2.94 \\
\hline $\mathrm{EC}(\mu \mathrm{S} / \mathrm{cm})$ & 350 & 1525 & 783.6 & 282.2 & 400 & 63 & 92.6 \\
\hline $\operatorname{TDS}(\mathrm{mg} / \mathrm{L})$ & 137 & 1414 & 507.28 & 209.24 & 1000 & 1 & 1.47 \\
\hline $\mathrm{TH}(\mathrm{mg} / \mathrm{L})$ & 35 & 530 & 215.7 & 97.13 & 300 & 10 & 14.7 \\
\hline $\mathrm{Na}^{+}(\mathrm{mg} / \mathrm{L})$ & 15 & 324 & 90.87 & 65.04 & 200 & 4 & 5.88 \\
\hline $\mathrm{K}^{+}(\mathrm{mg} / \mathrm{L})$ & 0.2 & 34 & 6.42 & 5.07 & 12 & 6 & 8.82 \\
\hline $\mathrm{Mg}^{2+}(\mathrm{mg} / \mathrm{L})$ & 1.0 & 73 & 20.78 & 13.53 & 50 & 3 & 4.41 \\
\hline $\mathrm{Ca}^{2+}(\mathrm{mg} / \mathrm{L})$ & 16 & 132 & 52.93 & 24.97 & 100 & 4 & 5.88 \\
\hline $\mathrm{Fe}^{2+}(\mathrm{mg} / \mathrm{L})$ & 0.1 & 4.16 & 0.54 & 0.67 & 0.3 & 37 & 54.4 \\
\hline $\mathrm{F}^{-}(\mathrm{mg} / \mathrm{L})$ & 0.01 & 3.95 & 0.54 & 0.52 & 1.5 & 2 & 2.94 \\
\hline $\mathrm{Cl}^{-}(\mathrm{mg} / \mathrm{L})$ & 9.6 & 167 & 46.78 & 29.25 & 250 & 0 & 0.0 \\
\hline $\mathrm{SO}_{4}{ }^{2-}(\mathrm{mg} / \mathrm{L})$ & 22 & 498 & 117.5 & 86.32 & 250 & 4 & 5.88 \\
\hline $\mathrm{HCO}_{3}{ }^{-}(\mathrm{mg} / \mathrm{L})$ & 100 & 510 & 243.65 & 90.93 & 250 & 26 & 38.23 \\
\hline $\mathrm{NO}_{3}-\mathrm{N}(\mathrm{mg} / \mathrm{L})$ & $<0.1$ & 4.2 & 0.30 & 0.55 & 10 & 0 & 0.0 \\
\hline
\end{tabular}

* Number of samples beyond (WHO) limits.

The turbidity value varied between 0 and 7 Nephelometric Turbidity Units (NTUs) with an average value of 2.52 NTUs, and only three samples showed high turbidity. The higher turbidity in the groundwater system of the area belonged to a shallow-depth well due to contamination exposure compared with the deep aquifer and mid-depth aquifer. Thus, surface recharge, water runoff, weathering processes, and industrial effluents can further increase the turbidity in the water system of the area. Moreover, high turbidity also results from shallow and poorly constructed wells that can cause high turbidity [29]. The most acceptable EC limit in drinking water is $400 \mu \mathrm{S} / \mathrm{cm}$ (WHO, 2006). The EC values ranged between $350 \mu \mathrm{S} / \mathrm{cm}$ and $1525 \mu \mathrm{S} / \mathrm{cm}$ with a mean value of $783.6 \mu \mathrm{S} / \mathrm{cm}$. The groundwater ion concentrations were directly associated with the EC, resulting in higher salinity and dissolved concentrations. However, $92.6 \%$ of the samples exceeded the permissible limits. The TDS levels ranged from 137.0 to $1414 \mathrm{mg} / \mathrm{L}$ in the study area with a mean of $707.3 \mathrm{mg} / \mathrm{L}$. Water with more than $1000 \mathrm{mg} / \mathrm{L}$ dissolved solids typically gives an unpleasant taste or renders the water unsuitable. The high TDS value affects the water's taste, hardness, and corrosive properties [46]. The maximum permissible guideline value of TDS recommended is $1000 \mathrm{mg} / \mathrm{L}$ [43].

The total hardness varied from 35.0 to $530 \mathrm{mg} / \mathrm{L}$ with an average of $215.7 \mathrm{mg} / \mathrm{L}$. The water could be classified as very hard if the TH was more than $300.0 \mathrm{mg} / \mathrm{L}$ [47]. Ten samples from the study area were under the very hard category. The concentrations of the cations could be written as $\mathrm{Na}^{+}>\mathrm{Ca}^{2+}>\mathrm{Mg}^{2+}>\mathrm{K}^{+}>\mathrm{Fe}^{2+}$. Similarly, the concentrations of the anions were in the order of $\mathrm{HCO}_{3}{ }^{-}>\mathrm{Cl}^{-}>\mathrm{SO}_{4}{ }^{2-}>\mathrm{F}^{-}>\mathrm{NO}_{3}{ }^{-}$.

The groundwater sodium $(\mathrm{Na}+$ ) concentrations ranged from $15.0 \mathrm{mg} / \mathrm{L}$ to $324.0 \mathrm{mg} / \mathrm{L}$ with a mean of $90.87 \mathrm{mg} / \mathrm{L}$. The maximum permissible limit for $\mathrm{Na}^{+}$is $200 \mathrm{mg} / \mathrm{L}$, according to [43]. The most common causes of elevated levels of $\mathrm{Na}^{+}$in groundwater are salt deposit erosion and $\mathrm{Na}^{+}$-bearing rock minerals. Natural brackish water from some aquifers is also absorbed by halite mineral water $[4,48]$. Agricultural byproducts may be another source of sodium in groundwater in the study region [8]. The concentrations of $\mathrm{Ca}^{2+}$ and $\mathrm{Mg}^{2+}$ were found to be $16-34 \mathrm{mg} / \mathrm{L}$ and 1-73 mg/L, respectively, with mean values of $46.78 \mathrm{mg} / \mathrm{L}$ and $20.78 \mathrm{mg} / \mathrm{L}$, respectively. The permissible limit for $\mathrm{Ca}^{2+}$ is $100 \mathrm{mg} / \mathrm{L}$, and for $\mathrm{Mg}^{2+}$, it is $50 \mathrm{mg} / \mathrm{L}$. According to the guidelines in [49], four samples had increased 
$\mathrm{Ca}^{2+}$ levels, and three samples had increased $\mathrm{Mg}^{2+}$ levels. Figure 2a shows carbonate weathering releasing $\mathrm{Ca}^{++}$and $\mathrm{Mg}^{2+}$, and Figure $2 \mathrm{~b}$ reflects the $\mathrm{Na}+\mathrm{K}$ against the total cations. Potassium $\left(\mathrm{K}^{+}\right)$concentrations in the groundwater ranged from 0.2 to $34 \mathrm{mg} / \mathrm{L}$, with an average of $6.42 \mathrm{mg} / \mathrm{L}$. According to [43], a maximum $\mathrm{K}^{+}$concentration of $12 \mathrm{mg} / \mathrm{L}$ is considered acceptable in the groundwater. In the study area, six samples exceeded the permissible limits. $\mathrm{K}^{+}$is produced in groundwater by weathering potassium-bearing rocks such as sylvite $(\mathrm{KCl})$ and silicates, especially clay minerals [4]. $\mathrm{K}^{+}$may also be added to groundwater by fertilizers and the breakdown of waste materials [50].
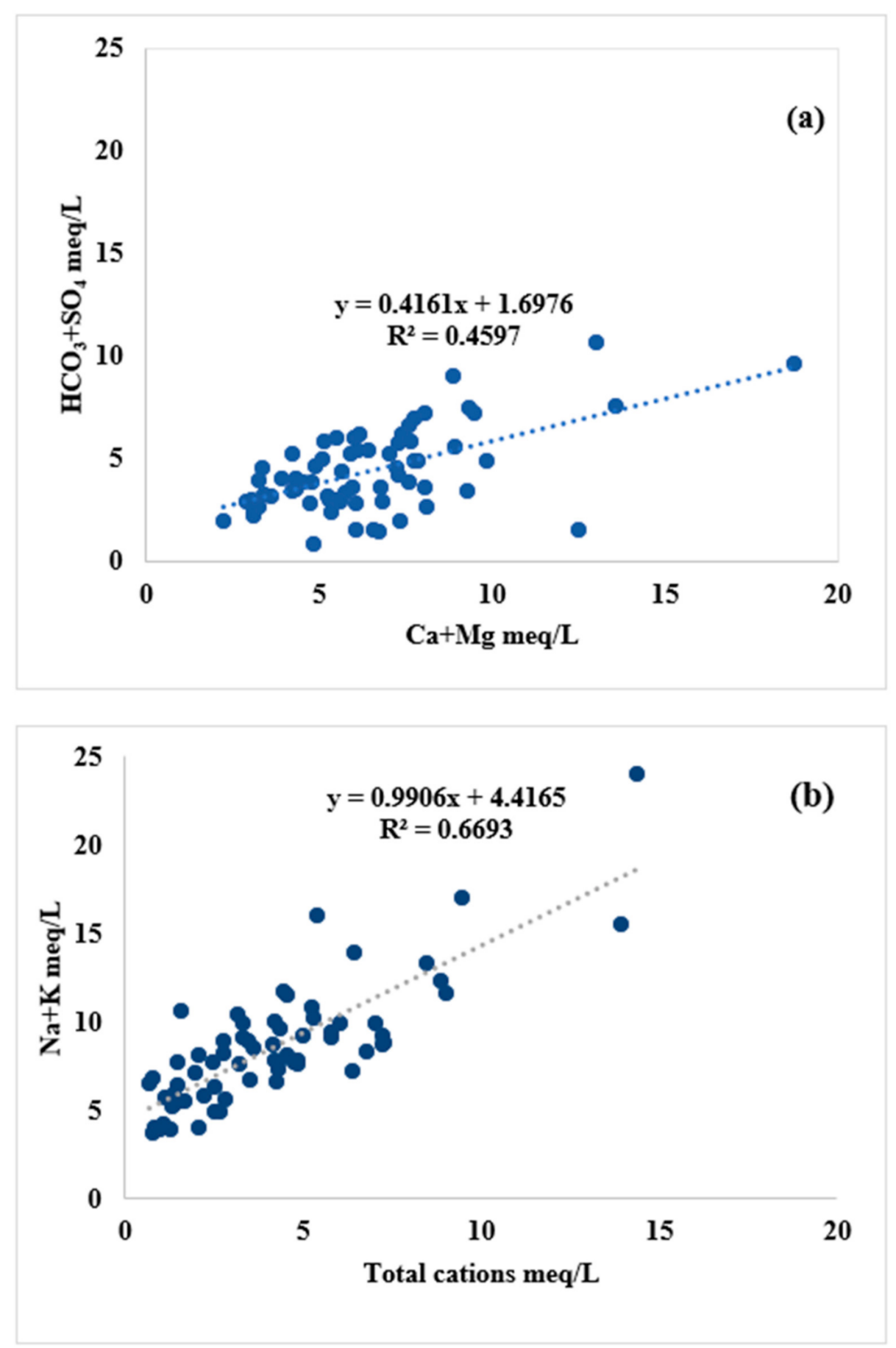

Figure 2. (a) Carbonate weathering triggering $\mathrm{Ca}^{++}$and $\mathrm{Mg}^{++}$in the groundwater. (b) $\mathrm{Na}+\mathrm{K}$ versus total cations. 
Iron $\left(\mathrm{Fe}^{2+}\right)$ concentrations varied from $0.1-0.54 \mathrm{mg} / \mathrm{L}$ with an average of $0.54 \mathrm{mg} / \mathrm{L}$. The maximum permissible concentration of iron allowed in the groundwater according to [43] is $0.3 \mathrm{mg} / \mathrm{L}$. The higher $\mathrm{Fe}^{2+}$ concentration in the groundwater system was due to the ferruginous minerals of the Earth's crust.

The most dominant anion in the study area was $\mathrm{HCO}_{3}{ }^{-}$, with concentrations that varied from 100 to $510 \mathrm{mg} / \mathrm{L}$ and a mean of $243.7 \mathrm{mg} / \mathrm{L}$. In our study area, $38 \%$ of the samples exceeded the permissible limit. The presence of organic matter in the aquifer that is oxidized to produce carbon dioxide, promoting mineral dissolution, results in the release of bicarbonate in the groundwater of the study area [51]. $\mathrm{SO}_{4}{ }^{2-}$ concentrations ranged from 22.0 to $498.0 \mathrm{mg} / \mathrm{L}$ with an average of $117.55 \mathrm{mg} / \mathrm{L}$. The permissible limit for $\mathrm{SO}_{4}{ }^{2-}$ is $250 \mathrm{mg} / \mathrm{L}$, and $5.9 \%$ of the samples were found above the allowable limit of the WHO. In addition to water-rock interaction, a high $\mathrm{SO}_{4}{ }^{2-}$ content may also be contributed by anthropogenic sources in the study region [8,51].

The $\mathrm{Cl}^{-}$ion is an essential element found in most groundwater in the world. Groundwater $\mathrm{Cl}^{-}$depends on many variables, such as weathering, sedimentary leaching of rocks, and anthropogenic sources $[8,52]$. The $\mathrm{Cl}^{-}$content in the groundwater of the study area varied from 9.6 to $167 \mathrm{mg} / \mathrm{L}$ with a mean of $46.7 \mathrm{mg} / \mathrm{L}$. The nitrates in the groundwater were between 0 and $4.2 \mathrm{mg} / \mathrm{L}$ with a mean value of $0.30 \mathrm{mg} / \mathrm{L}$. Anthropogenic sources cause the pollution of $\mathrm{NO}_{3}-\mathrm{N}$ [53].

The $\mathrm{F}^{-}$concentration in the groundwater of the study area ranged from 0.01 to $3.95 \mathrm{mg} / \mathrm{L}$, with a mean of $0.54 \mathrm{mg} / \mathrm{L} \mathrm{F}^{-}$is primarily attributed to the oxidation of minerals and the weathering of granite and igneous rocks. Fluoride is a vital component of the human body, and the fluoride content of potable water should not reach $1.5 \mathrm{mg} / \mathrm{L}$ [43]. Long-term exposure to fluoride-contaminated water causes dental and skeletal fluorosis [54,55]. In the KL-3 and KL-7 groundwater samples, the fluoride concentration was beyond the permitted limits. Fluoride concentrations are induced by the dissolution of fluorides comprising minerals from granite and gneiss rock [56].

Cation exchange mechanisms with greater alkaline $\mathrm{pH}, \mathrm{HCO}_{3}{ }^{-}$, and lower $\mathrm{Ca}^{2+}$ levels in groundwater increase $\mathrm{F}^{-}$pollution [55]. The formation of higher $\mathrm{F}^{-}$in groundwater is influenced by water-rock interactions and dry weather conditions. In acidic circumstances, clay minerals adsorbed $\mathrm{F}^{-}$, which was then desorbed in alkaline $\mathrm{pH}$.

The Durov diagram is a useful graphical tool for representing hydrogeochemical data [57] (see Figure 3). In the groundwater, the mixed type was the most prevalent. A few samples were plotted in the $\mathrm{D}$ (sodium form) field, indicating that $\mathrm{Na}+\mathrm{K}$ predominated in the groundwater. On the other hand, there was a noticeable difference in the groundwater anions. The E field samples belonged to the bicarbonate type, suggesting the $\mathrm{HCO}_{3}{ }^{-}$dominant anion. Those samples were primarily characterized by freshwater (TDS $<1000 \mathrm{mg} / \mathrm{L}$ ) located in the aquifer recharge region. The other belonged to brackish water's sulfate and mixed water types, suggesting the combined effects of evaporation, water-rock contact, and human activities. 


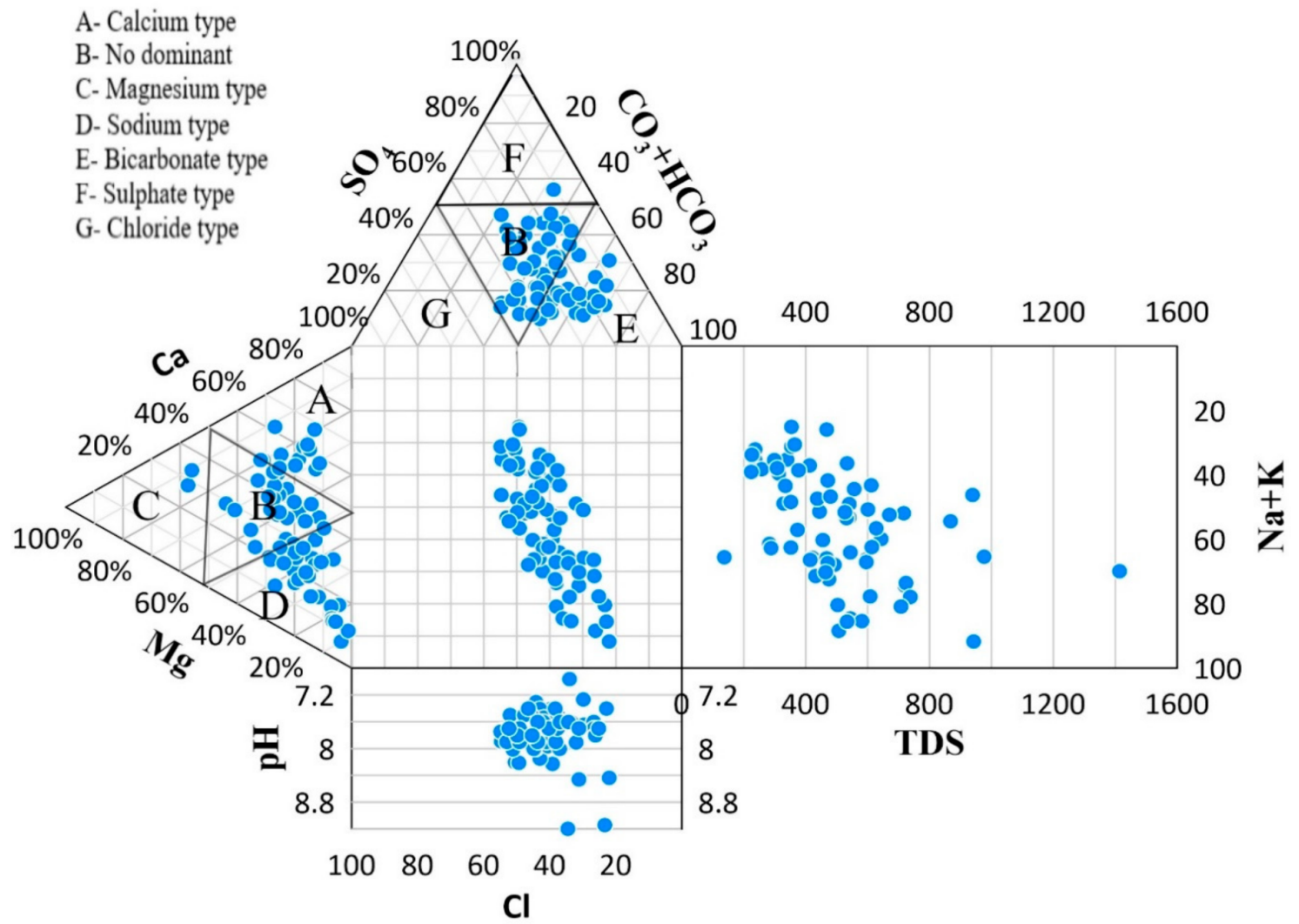

Figure 3. The Durov diagram of groundwater in the Khanewal district.

\subsection{Silicate Weathering}

The majority of the samples were above the aquiline of 1:1 in the scatter diagram of $(\mathrm{Ca}+\mathrm{Mg})$ vs. $\left(\mathrm{HCO}_{3}+\mathrm{SO}_{4}\right)$, indicating that carbonate weathering was a primary source of $\mathrm{Ca}^{2+}$ and $\mathrm{Mg}^{2+}$ [8]. The samples fell along the aquiline 1:1, implying that these ions resulted from carbonate and silicate weathering [58]. Carbonate weathering is responsible for ionic concentrations above the aquiline, while silicate weathering is responsible for those below the aquiline [59]. $\mathrm{HCO}_{3}{ }^{-}$is mainly derived from $\mathrm{CO}_{2}$ in the soil zone during the weathering of source rock minerals. The soil zone in the subsurface environment has a higher $\mathrm{CO}_{2}$ pressure due to the decomposition of organic matter and root respiration, which reacts with rainfall $\left(\mathrm{H}_{2} \mathrm{O}\right)$ to produce $\mathrm{HCO}_{3}{ }^{-}$[60]. However, the sample data would also plot above the 1:1 line of a $\mathrm{Na}^{+}+\mathrm{K}^{+}$vs. total cation graph, as silicate weathering is involved in the geochemical process. The data plot above the line confirms that silicate mineral weathering contributed to the groundwater chemistry (Figure 4a).

However, evaporite dissolution, silicate, carbonate rock weathering, and the effect of rock weathering on the groundwater chemistry were investigated using Na-normalized molar ratios (Figure $4 \mathrm{~b}$ ). As shown in Figure $4 \mathrm{~b}$, most of the samples were found in the bottom left and middle sections, indicating that evaporite dissolution and silicate weathering were dominant in the formation of the groundwater chemistry. The dissolved solutes were regulated mainly by carbonate weathering, as the distributed sample in the middle and upper right sections illustrates. 


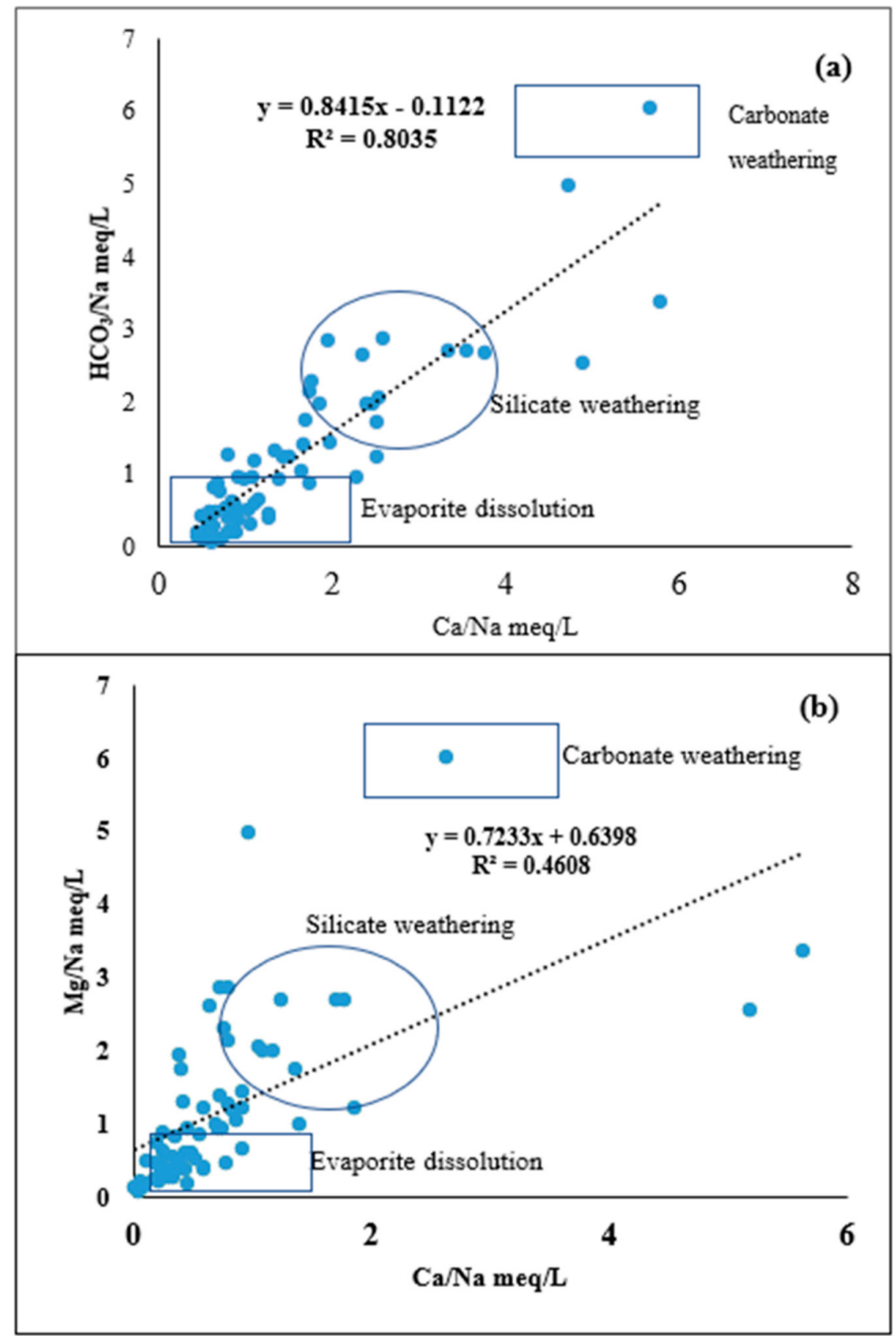

Figure 4. (a) Relationship of $\mathrm{HCO}_{3} / \mathrm{Na}$ versus $\mathrm{Ca} / \mathrm{Na}$. (b) $\mathrm{Mg} / \mathrm{Na}$ versus $\mathrm{Ca} / \mathrm{Na}$ to indicate evaporite mineral dissolution, carbonate, and silicate weathering.

In the study area, the sodium is released into the groundwater by halite and silicate minerals. If the mole ratio of $\mathrm{Na} / \mathrm{Cl}$ is $<1$, then halite dissolution may have occurred, or a mole ratio of $\mathrm{Na} / \mathrm{Cl}>1$ may indicate silicate dissolution [8]. In igneous rock, silicate minerals mostly occurred, as 95\% of the Earth's crust is composed of silicate minerals and the mantle. Silicon and oxygen are the primary components of silicate. The known minerals of silicon include quartz, mica, feldspar, pyroxene, olivine, amphibole, and clay minerals. In comparison, the common minerals include quartz, tridymite, coesite, cristobalite, keatite, and lechatelierite. The composition of the groundwater in our analysis showed that $85.3 \%$ of the samples had a $\mathrm{Na} / \mathrm{Cl}$ molar ratio of $\geq 1$, and $14.7 \%$ showed $\mathrm{Na} / \mathrm{Cl}<1$. Therefore, the molar ratio of $\mathrm{Na} / \mathrm{Cl}$ was $\geq 1$, denoting silicate weathering in the groundwater samples of our analysis, and the ratio less than 1 showed non-silicate weathering. In addition, the groundwater $\mathrm{Na} / \mathrm{Cl}$ ratio for this study varied between $0.45-8.1$ and 2.16 , respectively. However, the silicate minerals' range and average results were observed (1.03-8.10 and 2.42), and those for the non-silicate minerals were identified (0.45-0.93 and 0.70). As a result, the findings of this analysis indicate that both halite and silicate minerals caused groundwater contamination in the study region. Therefore, these findings are consistent with the studies mentioned above that were carried out in Pakistan $[4,8,48]$. 


\subsection{Hydrogeochemical Evolutional Processes}

The Gibbs diagram depicts three variables that influence the groundwater chemistry, including the dominance of evaporation, precipitation dominance, and weathering dominance $[8,55,61]$. According to Figure 5, most samples were plotted in the rock dominance region, indicating that rock dominance influenced most of the groundwater samples. The main contributor to mineral groundwater enrichment was the weathering of rock. The process by which the groundwater mixed dissolvable salts and minerals promoted the weathering of the parent rock. In addition, a long rock-water contact residence time also allows mineral dissolution [8]. Therefore, aquifer lithology and groundwater bedrock mineralogy have been highlighted as geochemical processes of importance in the study area.
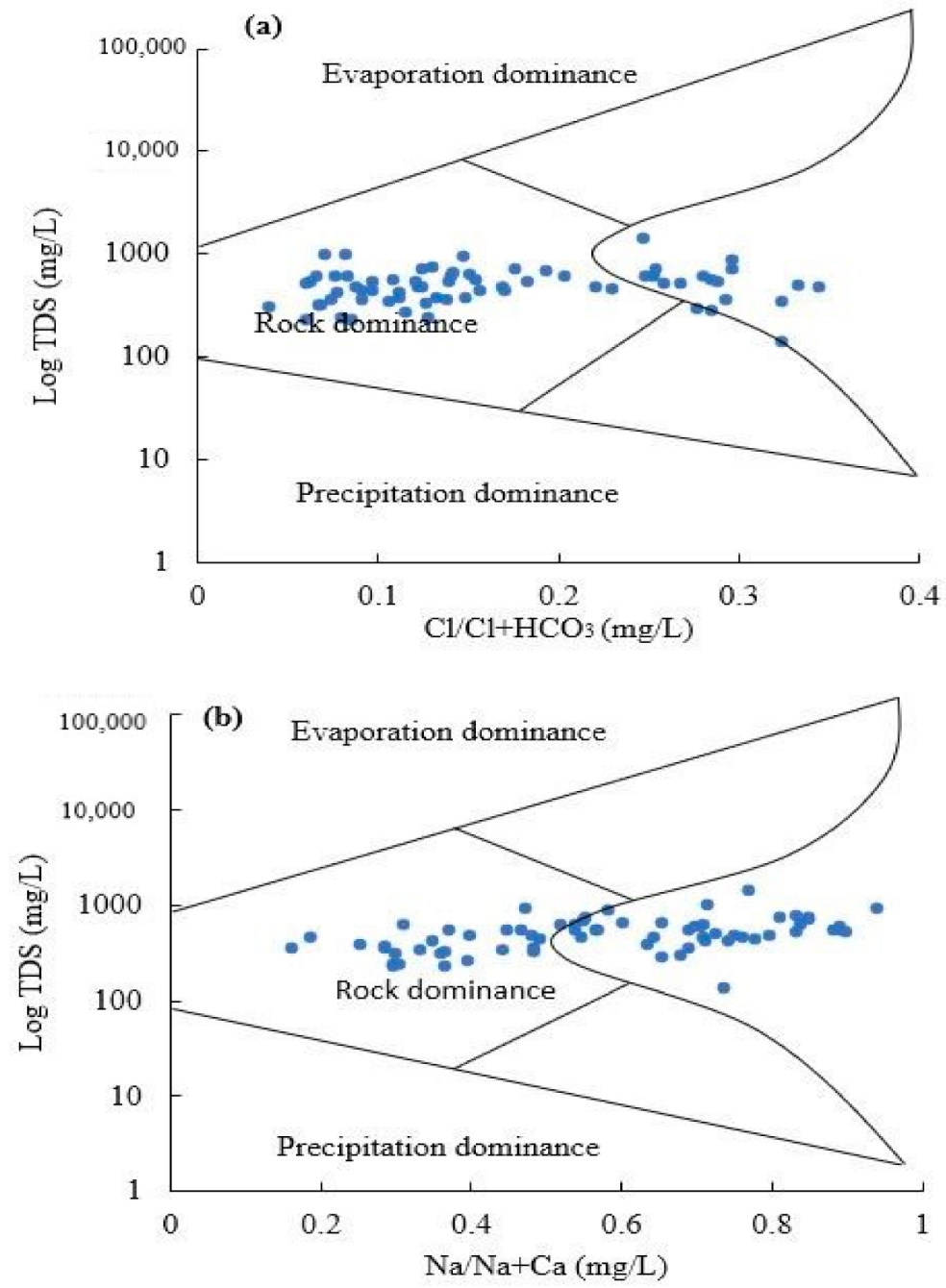

Figure 5. The Gibbs diagram demonstrates the ionic composition of the samples of groundwater. (a) $\mathrm{Cl} / \mathrm{Cl}+\mathrm{HCO}_{3} \mathrm{mg} / \mathrm{L}$ versus Log TDS. (b) $\mathrm{Na} / \mathrm{Na}+\mathrm{Ca} \mathrm{mg} / \mathrm{L}$ versus $\mathrm{Log}$ TDS.

Table 2 shows the correlation matrix of the physiochemical parameters of the study area for the groundwater samples. According to the Pearson correlation matrix, it was found that TDS had strong correlation with $\mathrm{Na}^{+}(0.83), \mathrm{HCO}_{3}^{-}(0.74), \mathrm{Cl}^{-}(0.60)$, and $\mathrm{SO}_{4}{ }^{2-}(0.86)$. All ionic concentrations increased with the increase in the TDS value. These ions were indicated to be primarily intended for sedimentary rock weathering. A poor correlation between $\mathrm{Na}^{+}$and $\mathrm{Cl}^{-}$may have been due to their genetic association with low evaporation. A low to moderate correlation between $\mathrm{SO}_{4}{ }^{2-}$ and $\mathrm{Ca}^{2+}$ suggests that gypsum dissolution did not occur, but the excess of $\mathrm{Ca}^{2+}$ was due to carbonate and the cation exchange [62], while a positive association between $\mathrm{Ca}^{2+}$ and $\mathrm{K}^{+}$could be attributed to the ion exchange and clay minerals. 
Table 2. Pearson correlation matrix of the study area's physiochemical parameters for groundwater.

\begin{tabular}{|c|c|c|c|c|c|c|c|c|c|c|c|c|c|}
\hline Parameter & $\mathrm{pH}$ & EC & TDS & $\mathrm{Na}^{+}$ & $\mathbf{K}^{+}$ & $\mathrm{Ca}^{2+}$ & $\mathrm{Mg}^{2+}$ & $\mathrm{Fe}$ & $\mathrm{HCO}_{3}$ & $\mathrm{Cl}^{-}$ & $\mathrm{SO}_{4}{ }^{2-}$ & $\mathbf{F}^{-}$ & $\mathrm{NO}_{3}{ }^{-}$ \\
\hline $\mathrm{pH}$ & 1 & & & & & & & & & & & & \\
\hline EC & -0.10 & 1 & & & & & & & & & & & \\
\hline TDS & -0.11 & 0.95 & 1 & & & & & & & & & & \\
\hline $\mathrm{Na}^{+}$ & 0.00 & 0.80 & 0.83 & 1 & & & & & & & & & \\
\hline $\mathrm{K}^{+}$ & -0.04 & 0.33 & 0.31 & 0.20 & 1 & & & & & & & & \\
\hline $\mathrm{Ca}$ & -0.13 & 0.35 & 0.38 & -0.09 & 0.22 & 1 & & & & & & & \\
\hline $\mathrm{Mg}$ & -0.13 & 0.43 & 0.48 & 0.054 & 0.19 & 0.40 & 1 & & & & & & \\
\hline $\mathrm{Fe}$ & 0.14 & 0.28 & 0.45 & 0.33 & 0.11 & 0.30 & 0.31 & 1 & & & & & \\
\hline $\mathrm{HCO}_{3}$ & -0.01 & 0.72 & 0.74 & 0.62 & 0.40 & 0.26 & 0.46 & 0.39 & 1 & & & & \\
\hline $\mathrm{Cl}$ & 0.00 & 0.52 & 0.60 & 0.56 & 0.12 & 0.07 & 0.22 & 0.38 & 0.23 & 1 & & & \\
\hline $\mathrm{SO}_{4}$ & -0.11 & 0.79 & 0.86 & 0.67 & 0.22 & 0.47 & 0.45 & 0.40 & 0.42 & 0.43 & 1 & & \\
\hline $\mathrm{F}$ & -0.01 & 0.53 & 0.49 & 0.58 & 0.06 & 0.01 & 0.02 & 0.08 & 0.51 & 0.07 & 0.36 & 1 & \\
\hline $\mathrm{NO}_{3}{ }^{-}$ & -0.10 & -0.01 & -0.02 & 0.05 & -0.10 & -0.14 & -0.06 & -0.04 & -0.08 & 0.25 & -0.09 & -0.10 & 1 \\
\hline
\end{tabular}

Note: The values in bold are different from 0 with a significance level alpha $=0.05$.

\subsection{Mineral Phases}

Measurements of the saturation could be used to estimate the subsurface mineralogy. Some minerals (calcite and dolomite) are typically present in equilibrium in subsurface and surface waters. SI calculations have shown in the current analysis that the carbonate minerals had varying degrees of saturation. The SI of the dolomite ranged from -1.19 to +2.66 , as shown in Figure 6, and that of calcite ranged from 0.57 to 1.54 . By contrast, the SI for gypsum ranged from -2.69 to -0.92 . These findings indicate that the dolomite and calcite showed variation in different samples, with both supersaturation and unsaturation levels. These minerals may precipitate $(\mathrm{SI}>1)$, and further dissolution (if $\mathrm{SI}<0$ ) is also possible. On the other hand, the Gypsum Value was below 0, indicating an unsaturation condition, and the findings also mean that $\mathrm{Na}^{+}$and $\mathrm{Cl}^{-}$may not be the primary source of halite. This research shows that silicate minerals led to groundwater pollution in the study region [63].

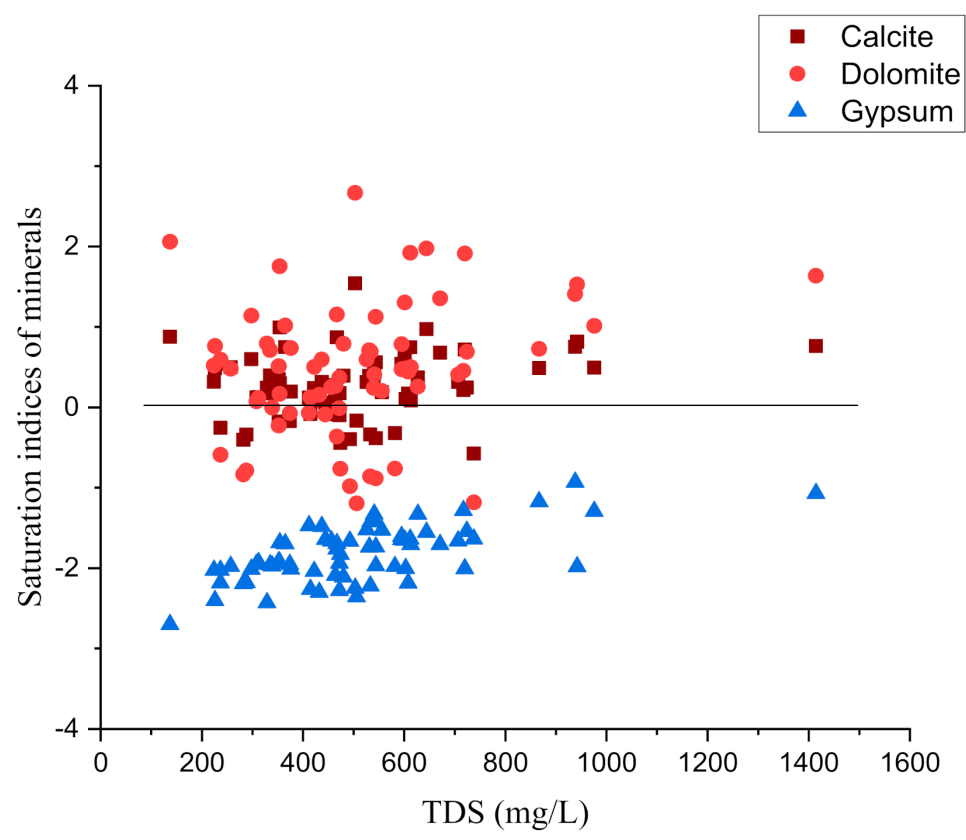

Figure 6. The variation of saturation indices of the selected minerals.

\subsection{Ion Exchange Processes}

The interaction between the $\mathrm{Na}+\mathrm{K}-\mathrm{Cl}$ and $\mathrm{Ca}+\mathrm{Mg}$ cations is widely used to identify cation exchange processes $\left(\mathrm{HCO}_{3}-\mathrm{SO}_{4}\right)$ [64]. Furthermore, the chlor-alkali index (CAI) can be used to determine whether the cation exchange is reverse or direct [8]. If the CAI 
value is greater than 0 , it indicates that the groundwater $\mathrm{Ca}^{2+}$ was exchanged for $\mathrm{Na}^{+}$in the aquifer, whereas a CAI value $>0$ indicates reverse cation exchange. Positive CAI- 1 and CAI-2 results suggest that $\mathrm{Na}^{+}$and $\mathrm{K}^{+}$ions are exchanged for $\mathrm{Mg}^{2+}$ and $\mathrm{Ca}^{2+}$ ions in water. Furthermore, when the $\mathrm{Mg}^{2+}$ and $\mathrm{Ca}^{2+}$ ion indices are negative, they are swapped with $\mathrm{Na}^{+}$and $\mathrm{K}^{+}$from rocks. This is an indication of an alkaline-chloride imbalance. The majority of the samples are shown in the lower left corner of Figure 7, showing reverse ion exchange. However, a small number of samples fell in the upper right corner, indicating direct ion exchange.

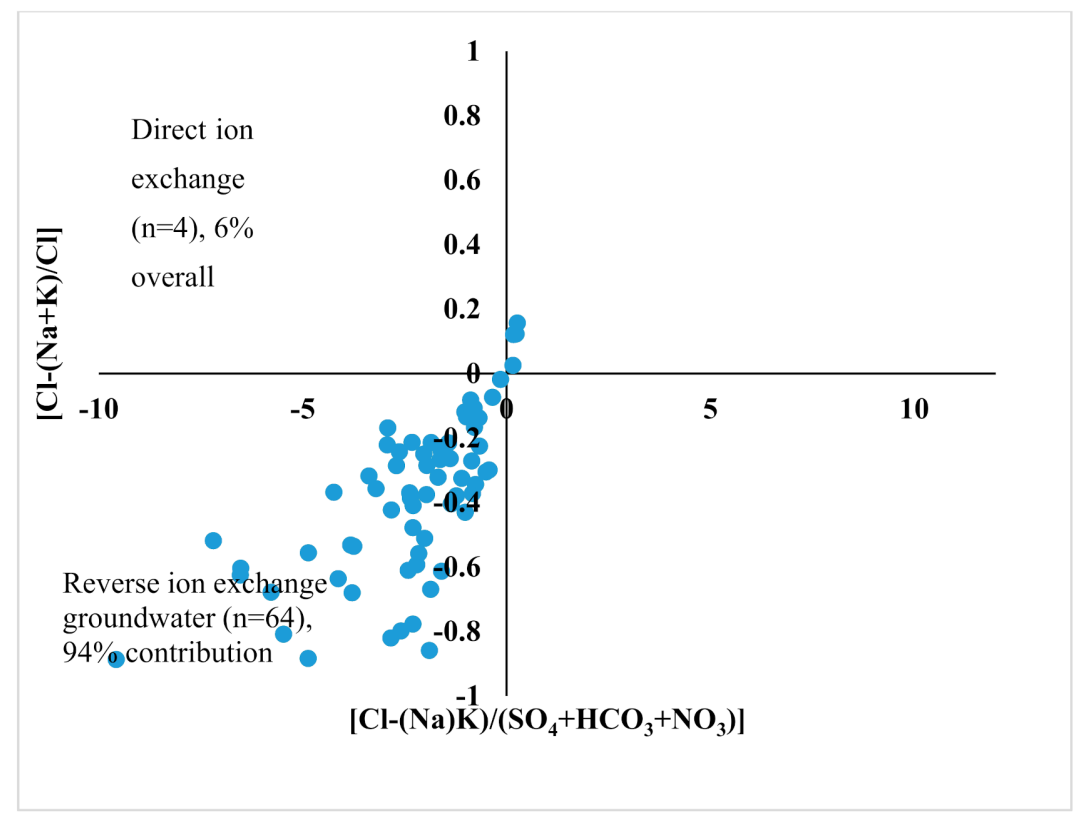

Figure 7. CAI-1 against CAI-2 shows the ion exchange processes in the groundwater samples of Khaniwal district, Pakistan.

The dominance of $\mathrm{HCO}_{3}{ }^{-}+\mathrm{SO}_{4}{ }^{2-}$ vs. $\mathrm{Ca}^{2+}+\mathrm{Mg}^{2+}$ could be related to cation exchange and silicate weathering. Only a few samples were discovered above the 1:1 line, demonstrating that reverse cation exchange is important in groundwater. Similarly, if cation exchange is the primary activity in groundwater, the linear relationship of $\mathrm{Na}^{+}+$ $\mathrm{K}^{+} \mathrm{Cl}$ vs. $\left(\mathrm{Ca}^{2+}+\mathrm{Mg}^{2+}\right)-\left(\mathrm{HCO}_{3}{ }^{-}+\mathrm{SO}_{4}{ }^{2-}\right)$ has a slope of -1 [65]. The linear fitting line had a slope of -1.002 (Figure $8 \mathrm{a}$ ), being close to -1 , indicating cation exchange in the groundwater system. In addition, in the groundwater, reverse cation exchange reactions should occur.

The lithogenic $\mathrm{Na}^{+}$in the groundwater was presumed and available from the meteoric origin, which was balanced by equivalent $\mathrm{Cl}^{-}$, and the equivalent $\mathrm{Cl}^{-}$was subtracted from $\mathrm{Na}^{+}$[4]. Cation exchange mechanisms control the ionic compositions of groundwater. The $\mathrm{R}^{2}$ value of $\mathrm{Na}^{+}$against $\left(\mathrm{Na}^{+} \mathrm{Cl}^{-}\right.$) meq/L was 0.99 (Figure $8 \mathrm{~b}$ ), favoring $\mathrm{Ca}^{++}$and $\mathrm{Mg}^{++}$ precipitation during ion exchange processes. The surface of the clay mineral absorbed $\mathrm{Na}^{+}$ and mobilized $\mathrm{F}^{-}$in the groundwater. The results of the ion exchange process are relatively supported by the previous studies $[8,66]$. 

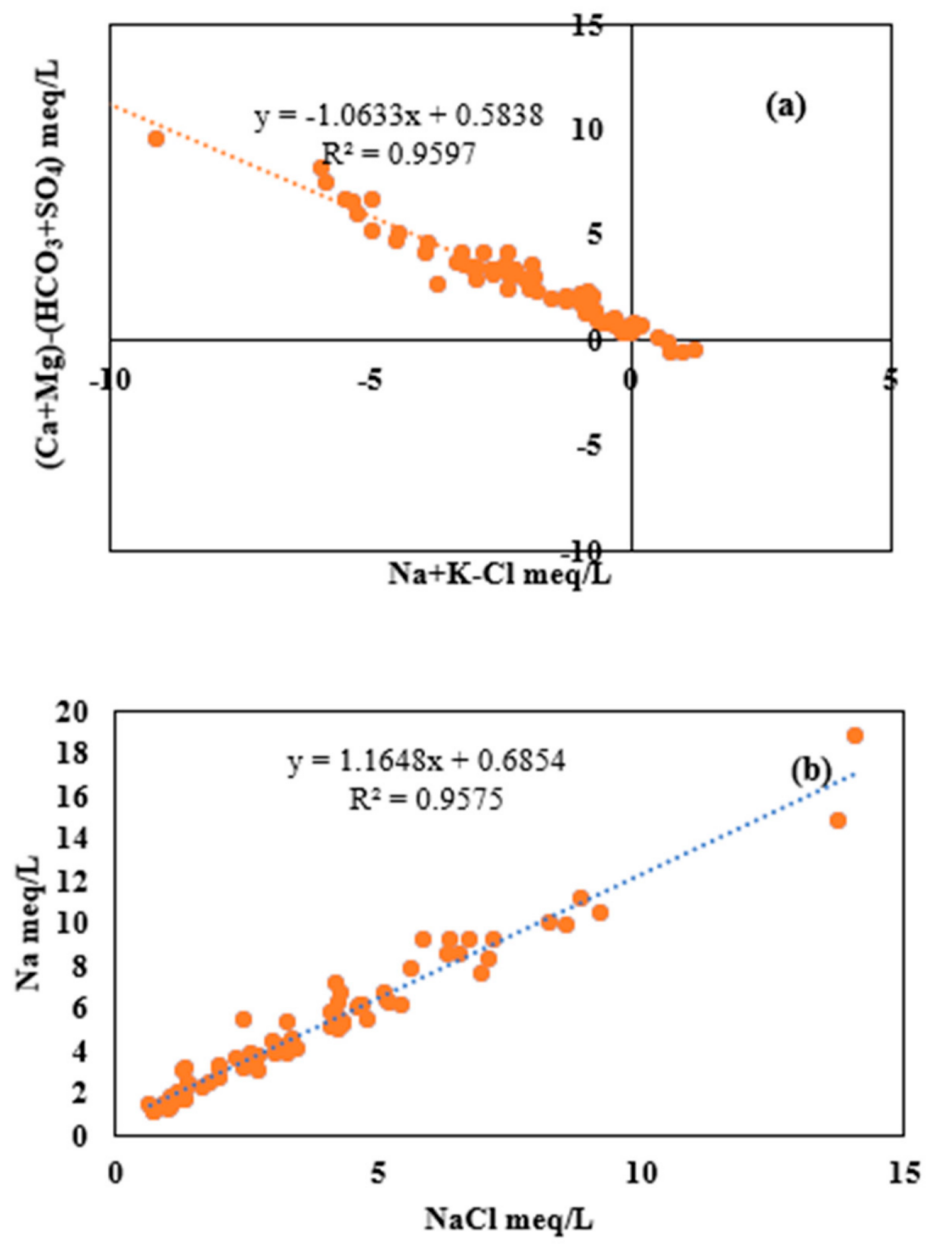

Figure 8. (a) Processes of $\mathrm{Na}^{+}$with $\mathrm{Ca}^{+2}$ discharge in the water system. (b) Source of $\mathrm{Na}^{+}$and $\mathrm{Cl}^{-}$ originating from meteoric water.

\subsection{Cluster Analysis}

Cluster analysis (CA) is a critical multivariate statistical technique often used to organize complex water data into various clusters better. In Ward's method, the squared Euclidean distance between the water variable was calculated for the similarity index. CA combined water observations that fell within the comparable cluster with the most similar geochemical results $[8,67]$. Thus, three cluster groups were constructed after Ward's method of measuring the Euclidean distance. C1 represents less polluted, C2 represents moderately polluted, and C3 indicates severely polluted.

The variability was $28.48 \%$ within the clusters and $71.52 \%$ between the clusters (Figure 9a). There were $n=43$ groundwater samples in the less contaminated cluster $\mathrm{C} 1$, while $\mathrm{C} 2$ contained $n=5$ and C 3 contained $n=20$. Cluster C1's percentage contribution was $63 \%$, Cluster C2's was $7.3 \%$, and Cluster C3's was $29.4 \%$. Cluster C3 was thus regarded as a highly contaminated cluster, often reflecting the degradation in the quality of the groundwater. The distance between the Cluster C1, C2 and C3 centroids was 0, 815.8836, and 473.5987; 815.8836, 0 , and 1282.7403; and 473.5987, 1282.7403, and 0 , respectively. The mean concentrations of the groundwater variables $\mathrm{pH}, \mathrm{EC}$, Tur, TDS, $\mathrm{TH}, \mathrm{Na}^{+}, \mathrm{K}^{+}, \mathrm{Ca}^{2+}$, $\mathrm{Mg}^{2+}, \mathrm{Fe}^{2+}, \mathrm{Cl}^{-}, \mathrm{SO}_{4}{ }^{2-}, \mathrm{F}^{-}$, and $\mathrm{NO}_{3}{ }^{-}$for the Clusters $\mathrm{C} 1, \mathrm{C} 2$ and $\mathrm{C} 3$ were $7.7,858,2.5$, $548,261,213,103,7.6,52,21,0.5,52,123,0.5$, and $0.34 ; 7.8,1436,4.4,1027,400,368,223,7.5$, $87,36.4,1.46,79,330,1.6$, and 0.14 ; and 7.9, 478, 2.14, 301, 170, 184, 33, 3.7, 46, 16.7, 0.44, 28, $50,0.6$, and 0.14 , respectively. 

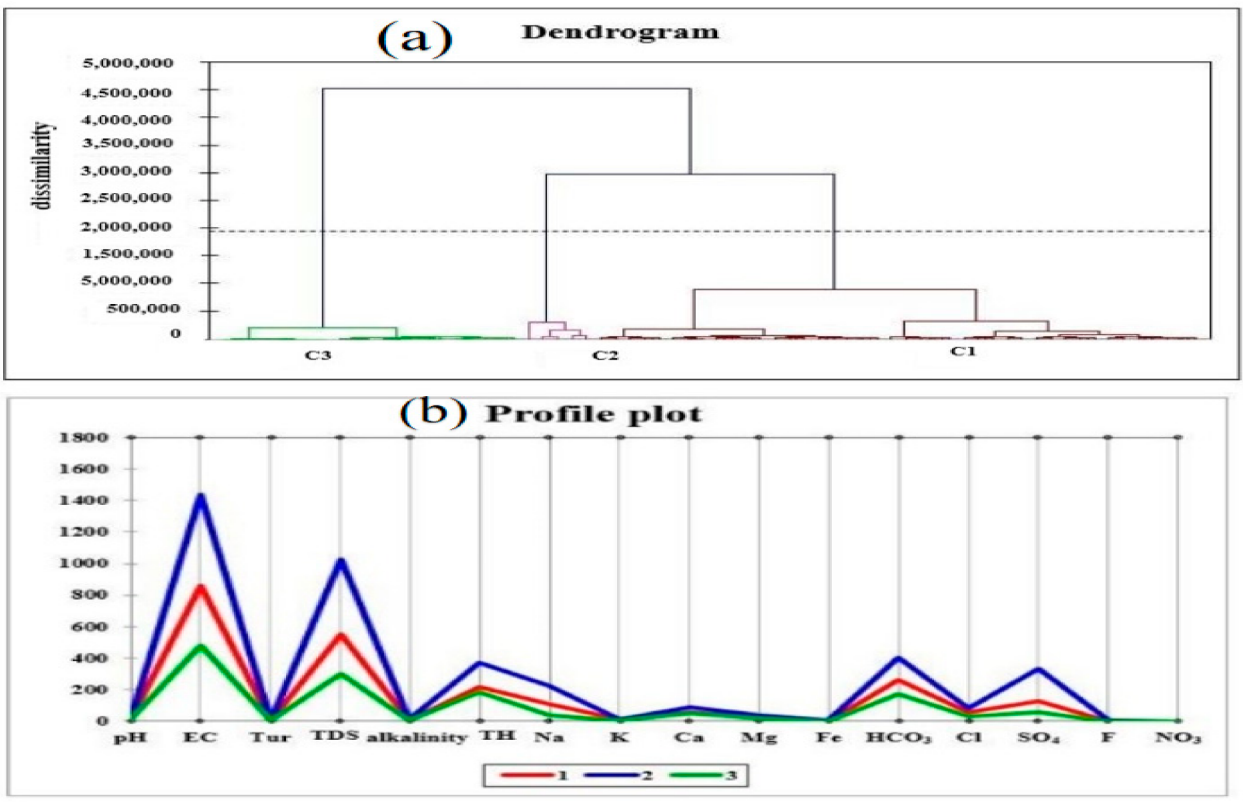

Figure 9. (a) Clustering of groundwater samples based on dissimilarity. (b) Groundwater variables.

For clusters $\mathrm{C} 1, \mathrm{C} 2$, and $\mathrm{C} 3$, the distances between the central objects were those from Observation 26, Observation 5, and Observation 57, respectively. In C1, C2, and C3, the distances for this observation were 0,863 , and 460.98; 863, 0 , and 1317.56; and $460.98,1317.56$, and 0 , respectively. The geochemistry of the central objects, however, viz. Observation 26, Observation 5, and Observation 57, for groundwater variables such as $\mathrm{pH}$, EC, Tur, TDS, TH, Na, K, Ca, Mg, Fe, Cl, $\mathrm{SO}_{4}, \mathrm{~F}$, and $\mathrm{NO}_{3}$ were 7.9, 850, 3, 544, 290, 210, $107,48,22,0.3,53,121,0.7$, and $0.1 ; 7.5,1525,5,976,490,380,212,9.2,84,41,0.82,44,266$, 1.09 , and 0.2 ; and $7.6,482,2,308,195,29,2.6,52,16,0.2,52,16,0.2,84,41,0.9$, and 0.2 in the central objects for clusters $\mathrm{C} 1, \mathrm{C} 2$, and $\mathrm{C} 3$, respectively.

\subsection{Principal Component Analysis}

The principal component analysis (PCA) results for the groundwater parameters are shown in Table 3 . The PCA results were obtained after varimax rotation to elucidate the acquired bases that influenced the groundwater $[8,67,68]$. For the groundwater parameters, F1, F2, F3, and F4 were derived with eigenvalues of 5.86, 2.20, 1.48, and 1.37, respectively, resulting in a total variance of $36.60 \%, 13.75 \%, 9.24 \%$, and $8.54 \%$, respectively.

The first factor (F1) represented $36.60 \%$ of the total variance with an eigenvalue of 5.86 as shown in the Table 3 . The significant correlation coefficient $(\mathrm{r})$ values of the groundwater variables (EC, TDS, $\mathrm{TH}, \mathrm{Na}, \mathrm{K}, \mathrm{Ca}, \mathrm{Mg}, \mathrm{Fe}, \mathrm{HCO}_{3}, \mathrm{Cl}$, and $\mathrm{SO}_{4}$ ) were calculated to be $0.91,0.97,0.66,0.72,0.38,0.50,0.60,0.56,0.78,0.54$, and 0.84 , respectively. F1 had a high contribution of loading factors for the above parameters in the PCA results, and F1 demonstrated the geogenic and anthropogenic sources in the research area by showing a high contribution of moderate and strong positive loadings for all groundwater. F1 indicates the ionic configuration of groundwater and resultant from mineral dissolution, ion exchange, and weathering of the host granitic rocks. The dissolution of gypsum- and calcium-carrying rocks, as well as the interaction of water and rock, initiate the source of $\mathrm{SO}_{4}{ }^{2-}$ and $\mathrm{HCO}_{3}{ }^{-}$. F1 is also linked to water salinity, as determined by EC and major ion chemistry. Natural processes, such as carbonate $\left(\mathrm{CaCO}_{3}\right)$ and mineral bearing, contributed significantly to the F1 component. High levels of major ions like $\mathrm{Ca}^{2+}, \mathrm{Mg}^{2+}, \mathrm{Na}^{+}$, and $\mathrm{Cl}^{-}$ may reflect anthropogenic sources which affect mineral water reactions $[4,8]$. 
Table 3. Rotated factor loadings for the groundwater samples in the Khanewal district.

\begin{tabular}{lcccc}
\hline Loading Factors & F1 & F2 & F3 & F4 \\
\hline Depth & 0.11 & 0.16 & -0.39 & -0.35 \\
$\mathrm{pH}$ & -0.08 & -0.12 & -0.46 & 0.51 \\
$\mathrm{EC}$ & 0.91 & -0.23 & 0.10 & -0.18 \\
$\mathrm{Tur}$ & 0.47 & 0.21 & -0.50 & 0.40 \\
$\mathrm{TDS}$ & 0.97 & -0.18 & 0.09 & -0.06 \\
$\mathrm{TH}$ & 0.66 & 0.69 & 0.19 & -0.02 \\
$\mathrm{Na}$ & 0.72 & -0.66 & -0.03 & -0.02 \\
$\mathrm{~K}$ & 0.38 & 0.06 & -0.18 & -0.15 \\
$\mathrm{Ca}$ & 0.50 & 0.66 & 0.10 & -0.06 \\
$\mathrm{Mg}$ & 0.60 & 0.53 & 0.19 & 0.02 \\
$\mathrm{Fe}$ & 0.56 & 0.14 & -0.20 & -0.07 \\
$\mathrm{HCO}$ & 0.78 & -0.11 & 0.40 & 0.39 \\
$\mathrm{Cl}$ & 0.54 & -0.30 & 0.09 & -0.11 \\
$\mathrm{SO}$ & -0.01 & -0.29 & -0.31 \\
$\mathrm{~F}$ & 0.84 & -0.46 & 0.64 & 0.30 \\
$\mathrm{NO}_{3}$ & 0.48 & -0.25 & 1.48 & 1.37 \\
Eigenvalue & -0.07 & 2.20 & 9.24 & 8.54 \\
Variability $(\%)$ & 5.86 & 13.75 & 59.59 & 68.13 \\
$\mathrm{Cumulative} \%$ & 36.60 & 50.35 & & \\
\hline
\end{tabular}

The second factor (F2) accounted for $13.75 \%$ of the overall variance, with an eigenvalue of 1.84. The strong correlation coefficient for $\mathrm{Mg}^{2+}$ and $\mathrm{Ca}^{2+}$, with correlation coefficients of 0.53 and 0.66 , respectively, were observed, with water forms of $\mathrm{HCO}_{3}{ }^{-} \mathrm{Ca}$ and $\mathrm{Mg}$ having a percentage contribution of component F2. The high concentrations of $\mathrm{Mg}^{2+}$ and $\mathrm{Ca}^{2+}$ might have been due to extreme evaporation, scarce precipitation, and a shallow water table influenced by irrigation water [13].

F3 and F4 accounted for $9.24 \%$ and $8.54 \%$ of the variability with eigenvalues of 1.48 and 1.37, respectively. The PCA results support the hydrogeochemical processes, and F3 and $\mathrm{F} 4$ had a significant correlation with $\mathrm{NO}_{3}{ }^{-}, \mathrm{pH}$, and $\mathrm{HCO}_{3}{ }^{-}$, with coefficient (r) values of $0.64,0.51$, and 0.63 , respectively. Both natural and anthropogenic factors caused groundwater pollution in the study area.

\subsection{Groundwater Suitability Evaluation for Drinking Purposes}

The Water Quality Index (WQI) is a vital groundwater quality parameter used to evaluate groundwater's aptness for drinking [69]. The WQI is a method that calculates the effect of the groundwater parameters on the groundwater quality, and it is measured by using the WHO's drinking standards [43]. There are five categories according to the WQI criteria: excellent $(<50)$, good $(>50)$, bad $(>100)$, very poor $(>200)$, and water not suitable for drinking (>300) [70]. Table 4 shows the WQI classification of the study area, listing the different types of groundwater based on the WQI references. It depicts more than $50 \%$ of the groundwater samples as not being safe for drinking purposes. A spatial distribution map of Figure 10 provided more information about the different types of water in the study region, where $2.94 \%$ of the samples were excellent for drinking, while $39.7 \%$ were poor, $11.76 \%$ were good, $27.94 \%$ were very poor, and $17.64 \%$ were not suitable for drinking. Furthermore, Figure 10 demonstrates that the majority of the samples in the groundwater of the study area were inappropriate for drinking purposes. 
Table 4. Water Quality Index (WQI) classification of the study area.

\begin{tabular}{llll}
\hline WQI & Water Type & No. of Samples & \% of Samples \\
\hline$(<50)$ & Excellent & 2 & 2.94 \\
$(>50)$ & Good & 8 & 11.76 \\
$(>100)$ & Poor & 27 & 39.7 \\
$(>200)$ & Very poor & 19 & 27.94 \\
$(>300)$ & Unsuitable for drinking & 12 & 17.64 \\
\hline
\end{tabular}

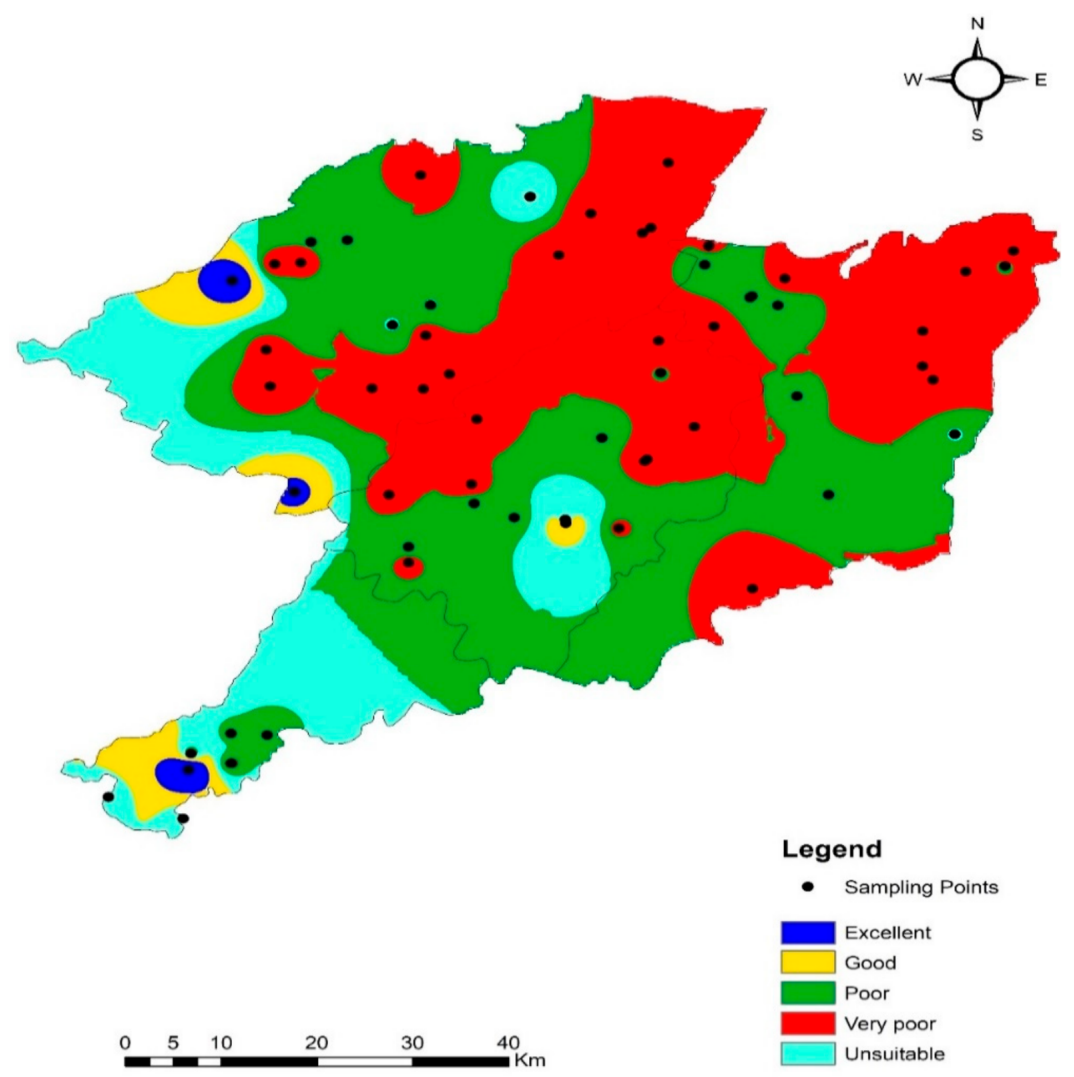

Figure 10. Groundwater suitability assessment for drinking purposes in the study area.

\subsection{Assessment for Irrigation Purposes}

The suitability of the groundwater in the study area for irrigation was assessed by using Wilcox and USSL diagrams, as well as other agricultural indices such as the sodium percentage (Na\%), sodium adsorption ratio (SAR), Permeability Index (PI), magnesium hazard $(\mathrm{MH})$, and Kelly ratio (KR). Table 5 summarizes the irrigation indices of the groundwater samples statistically. According to SAR, the sodium hazard in the groundwater could be rated as low (SAR10), medium (10-18), moderate (18-26), or very high (SAR > 26). The SAR ranged from 1.65 to 65.19 in the study area, with an average of 12.87, indicating a low, medium, and high risk of sodium. The USSL diagram (Figure 11a) shows 45 samples belonging to the $C_{2} S_{1}$ and $C_{3} S_{1}$ groups, indicating that they could be used for irrigation with minimal $\mathrm{Na}^{+}$exchange. Nine samples belonged to the $C_{3} S_{2}$ group, four to the $C_{3} S_{4}$ group, five to the $C_{2} S_{2}$ group, and five to the $C_{1} S_{1}$ group. These types of water are not suitable for agricultural use. 
Table 5. The statistical summary of irrigation indices.

\begin{tabular}{llllllll}
\hline Indices & Minimum & Maximum & Mean & S.D & $\begin{array}{l}\text { Permissible } \\
\text { Limit }\end{array}$ & $\begin{array}{l}\text { Unsuitable } \\
\text { Samples }\end{array}$ & $\begin{array}{l}\text { \% of Suitable } \\
\text { Samples }\end{array}$ \\
\hline PI & 34.78 & 113.5 & 70.29 & 18.13 & $>25$ & - & $13 \%$ \\
MH & 9.44 & 68.96 & 38.43 & 13.47 & 50 & 13 & $80.88 \%$ \\
KR & 0.11 & 8.68 & 1.25 & 1.55 & 1 & 29 & $57.35 \%$ \\
SAR & 1.07 & 7.99 & 2.81 & 1.13 & 18 & 13 & $80 \%$ \\
Na\% & 10.64 & 89.78 & 45.66 & 20.71 & 60 & 15 & $77.94 \%$ \\
\hline
\end{tabular}

$\mathrm{PI}=$ Pearmeability Index; $\mathrm{MH}$ = magnesium hazard; $\mathrm{KR}=$ Kelly Ratio; $\mathrm{SAR}$ = sodium adsorption ratio; $\mathrm{Na} \%$ = sodium percentage .

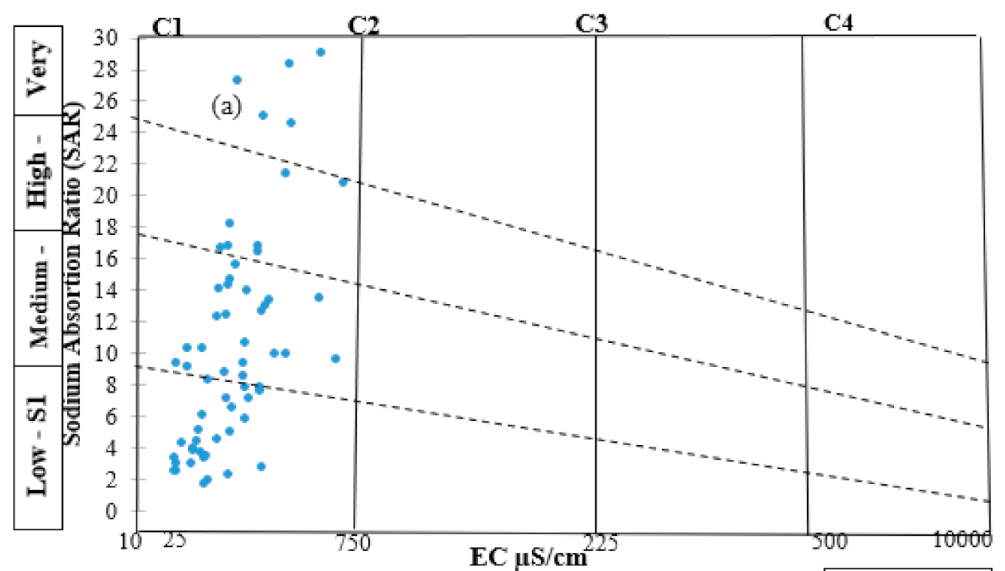

\begin{tabular}{|l|l|l|} 
Low-C1 & Medium - C2 & High - C3 \\
\hline
\end{tabular}

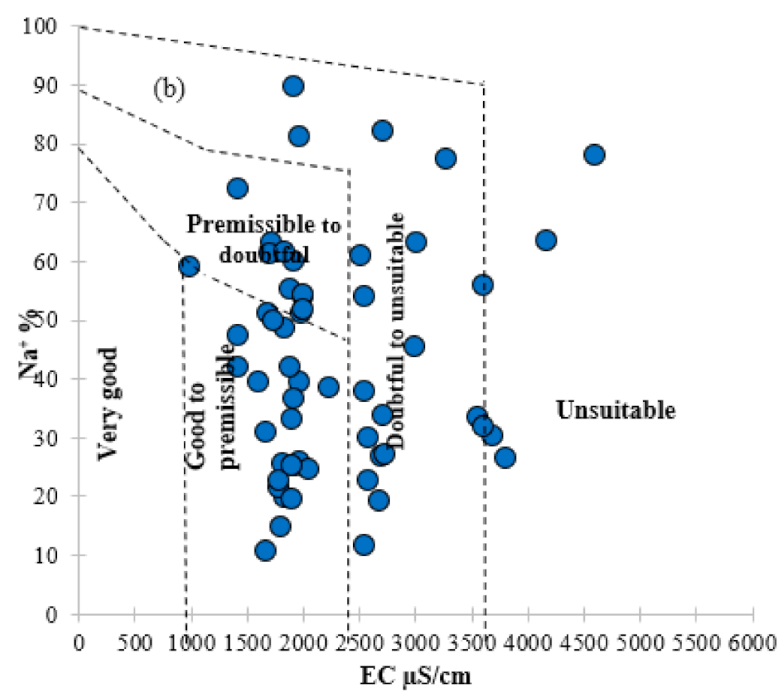

Figure 11. (a) Groundwater quality evaluation as sodium absorption ratio (SAR) vs. EC (uS/cm) with USSL diagram. (b) Wilcox diagram used for the classification of irrigation water, indicating $\%$ Na vs. EC.

The $\mathrm{Na}^{+\%}$ varied from $10.64 \%$ to $89.78 \%$ with a mean value of $45.66 \%$, and $77.94 \%$ of the samples were suitable for agricultural purposes. A high percentage of $\mathrm{Na}^{+}$causes deflocculation, soil tilt, and permeability. Groundwater containing less than $60 \% \mathrm{Na}+$ is considered acceptable for irrigation usage. Wilcox's diagram further defines groundwater for irrigation, where EC is graphed against the percentage of $\mathrm{Na}^{+}$used. As in Figure $11 \mathrm{~b}$, approximately $36.7 \%$ of the samples were good to permissible, followed by $22 \%$ percent belonging to doubtful to permissible, and $22 \%$ of the samples fell into doubtful categories for irrigation use, while $11.7 \%$ were unfit for irrigation use. 
The Permeability Index (PI) is a primary factor for assessing water appropriateness for irrigation. According to [8], class 1 ( $>75 \%$, suitable), class 2 (25-75\%, good), and class 3 (less than $25 \%$, unsuitable) are the three classifications for PI.

The study area findings were in the range of 34.7-70.3, with a mean value of 70.3. Most samples fell into class 1 under the Deneen classification sampling programs, suggesting that the groundwater was suitable for irrigation. A magnesium hazard less than 50 is considered acceptable for irrigation purposes, while one greater than 50 is unfit for irrigation, and the crop yield declines as soils become more alkaline [4,8]. With a mean value of 38.42 , the magnesium value for the study area varies from 9.4 to 68.95 . In 13 samples, the magnesium hazard was more than 50 , so these were unsuitable for irrigation, while others were good for irrigation.

The Kelly ratio ranged from 0.12 to 8.6 with a mean value of 1.29 . If the Kelly ratio is less than one, it is considered ideal for irrigation purposes [71]. Kelly's ratio was lower than one in 39 samples, which means that the water sample was suitable for irrigation, whereas the 29 samples with a ratio greater than 1 were not suitable for irrigation in the study area.

\section{Conclusions}

For the current study, a combination of statistical analysis, graphical techniques, and hydrochemical modeling was utilized to gain a full understanding of the groundwater chemistry and its suitability for drinking and agricultural uses in the designated research region. Statistical analysis shows that cations were abundant in the following order: $\mathrm{Na}^{+}>$ $\mathrm{Ca}^{2+}>\mathrm{Mg}^{2+}>\mathrm{K}^{+}>\mathrm{Fe}^{2+}$. Meanwhile, anions were abundant in the following order: $\mathrm{HCO}_{3}{ }^{-}$ $>\mathrm{Cl}^{-}>\mathrm{SO}_{4}{ }^{2-}>\mathrm{F}^{-}>\mathrm{NO}_{3}{ }^{-}$. The high concentrations of sodium and bicarbonate ions in the research illustrate the process of silicate weathering, which regulates the chemistry of key ions in groundwater. Furthermore, ion exchange and rock weathering processes, such as the dissolution of albite, carbonate, and gypsum minerals, control the rock-water interactions that regulate the groundwater hydrochemistry. The Gibbs diagrams showed rock weathering as the primary source of the hydrochemical compositions of the groundwater.

Furthermore, the Durov diagram revealed no dominating ions, although some cation and anion samples revealed dominance in the $\mathrm{Na}^{+}-\mathrm{K}^{+}$type, and some samples revealed observable chemistry of the types $\mathrm{HCO}_{3}{ }^{-}$and $\mathrm{Cl}^{-}$. The geochemical modeling showed undersaturation of the evaporite mineral gypsum and supersaturation of carbonate minerals calcite and dolomite. The ion exchange method showed that reverse ion exchange was dominant. Multivariate analysis statistically proved the relation between different variables and their hydrogeochemistry in the groundwater. The WQI showed that $50 \%$ of the groundwater samples were unfit for drinking purposes. However, according to the agricultural indices, approximately $32 \%$ of the groundwater samples were unsuitable for irrigation. Anthropogenic activities and sedimentary rock weathering play a significant role in the depletion of the groundwater system in the study area. It is highly recommended that the local government and higher authorities control groundwater pollution in the surrounding vicinity of the Khanewal district.

Author Contributions: Writing-original draft, J.I. and C.S.; conceptualization, J.I. and C.S.; methodology, J.I., A.R. and M.Y.J.B.; software, J.I., N.U.R., N.Y., M.Y.J.B. and S.A.T.; formal analysis, J.I., M.Y.J.B. and Z.U.; investigation, J.I., G.R., N.U.R. and M.Y.J.B.; resources, C.S.; data curation, J.I.; review and editing: C.S., M.Y.J.B., Earjh and M.M.S.; visualization, C.S., M.Y.J.B. and S.A.T.; supervision, C.S. All authors have read and agreed to the published version of the manuscript.

Funding: The research work was supported by National Natural Science Foundation of China (Nos.4217072366).

Institutional Review Board Statement: Not applicable.

Informed Consent Statement: All the related authors have obtained informed consent.

Data Availability Statement: Not applicable. 
Acknowledgments: The research work was supported by National Natural Science Foundation of China (Nos.4217072366).

Conflicts of Interest: The authors declare no conflict of interest.

\section{References}

1. Carrard, N.; Foster, T.; Willetts, J. Groundwater as a Source of Drinking Water in Southeast Asia and the Pacific: A Multi-Country Review of Current Reliance and Resource Concerns. Water 2019, 11, 1605. [CrossRef]

2. Vincy, M.V.; Brilliant, R.; Pradeepkumar, A.P. Hydrochemical characterization and quality assessment of groundwater for drinking and irrigation purposes: A case study of Meenachil River Basin, Western Ghats, Kerala, India. Environ. Monit. Assess. 2014, 187, 1-19. [CrossRef] [PubMed]

3. Baloch, M.Y.J.; Talpur, S.A.; Talpur, H.A.; Iqbal, J.; Mangi, S.H.; Memon, S. Effects of Arsenic Toxicity on the Environment and Its Remediation Techniques: A Review. J. Water Environ. Technol. 2020, 18, 275-289. [CrossRef]

4. Rashid, A.; Farooqi, A.; Gao, X.; Zahir, S.; Noor, S.; Khattak, J.A. Geochemical modeling, source apportionment, health risk exposure and control of higher fluoride in groundwater of sub-district Dargai, Pakistan. Chemosphere 2020, 243, 125409. [CrossRef]

5. Sakram, G.; Adimalla, N. Hydrogeochemical characterization and assessment of water suitability for drinking and irrigation in crystalline rocks of Mothkur region, Telangana State, South India. Appl. Water Sci. 2018, 8, 1-21. [CrossRef]

6. Nlend, B.; Celle-Jeanton, H.; Huneau, F.; Garel, E.; Boum-Nkot, S.N.; Etame, J. Shallow urban aquifers under hyper-recharge equatorial conditions and strong anthropogenic constrains. Implications in terms of groundwater resources potential and integrated water resources management strategies. Sci. Total. Environ. 2020, 757, 143887. [CrossRef]

7. Medici, G.; Baják, P.; West, L.; Chapman, P.; Banwart, S. DOC and nitrate fluxes from farmland; impact on a dolostone aquifer KCZ. J. Hydrol. 2021, 595, 125658. [CrossRef]

8. Baloch, M.Y.J.; Zhang, W.; Chai, J.; Li, S.; Alqurashi, M.; Rehman, G.; Tariq, A.; Talpur, S.A.; Iqbal, J.; Munir, M.; et al. Shallow Groundwater Quality Assessment and Its Suitability Analysis for Drinking and Irrigation Purposes. Water 2021, 13, 3361. [CrossRef]

9. Hussein, E.E.; Fouad, M.; Gad, M.I. Prediction of the pollutants movements from the polluted industrial zone in 10th of Ramadan city to the Quaternary aquifer. Appl. Water Sci. 2019, 9, 20. [CrossRef]

10. Mabrouk, M.B.; Jonoski, A.; Solomatine, D.; Uhlenbrook, S. A review of seawater intrusion in the Nile Delta groundwater system-the basis for assessing impacts due to climate changes and water resources development. Hydrol. Earth Syst. Sci. Discuss. 2013, 10, 10873-10911.

11. Shah, S.H.I.A.; Yan, J.; Ullah, I.; Aslam, B.; Tariq, A.; Zhang, L.; Mumtaz, F. Classification of Aquifer Vulnerability by Using the DRASTIC Index and Geo-Electrical Techniques. Water 2021, 13, 2144. [CrossRef]

12. Akhter, G.; Hasan, M. Determination of aquifer parameters using geoelectrical sounding and pumping test data in Khanewal District, Pakistan. Open Geosci. 2016, 8, 630-638. [CrossRef]

13. Guo, X.; Zuo, R.; Shan, D.; Cao, Y.; Wang, J.; Teng, Y.; Fu, Q.; Zheng, B. Source apportionment of pollution in groundwater source area using factor analysis and positive matrix factorization methods. Hum. Ecol. Risk Assess. Int. J. 2017, 23, 1417-1436. [CrossRef]

14. Tariq, M.I.; Afzal, S.; Hussain, I. Degradation and persistence of cotton pesticides in sandy loam soils from Punjab, Pakistan. Environ. Res. 2006, 100, 184-196. [CrossRef]

15. Alam, F. Evaluation of hydrogeochemical parameters of groundwater for suitability of domestic and irrigational purposes: A case study from central Ganga Plain, India. Arab. J. Geosci. 2014, 7, 4121-4131. [CrossRef]

16. Tariq, S.R.; Shaheen, N.; Khalique, A.; Shah, M.H. Distribution, correlation, and source apportionment of selected metals in tannery effluents, related soils, and groundwater-a case study from Multan, Pakistan. Environ. Monit. Assess. 2010, 166, 303-312. [CrossRef]

17. Talib, M.A.; Tang, Z.; Shahab, A.; Siddique, J.; Faheem, M.; Fatima, M. Hydrogeochemical Characterization and Suitability Assessment of Groundwater: A Case Study in Central Sindh, Pakistan. Int. J. Environ. Res. Public Health 2019, 16, 886. [CrossRef]

18. Shahab, A.; Shihua, Q.; Rashid, A.; Hasan, F.U.; Sohail, M.T. Evaluation of Water Quality for Drinking and Agricultural Suitability in the Lower Indus Plain in Sindh Province, Pakistan. Pol. J. Environ. Stud. 2016, 25, 2563-2574. [CrossRef]

19. Adams, T.E. Water Resources Forecasting Within the Indus River Basin: A Call for Comprehensive Modeling. Indus River Basin 2019, 267-308

20. Raza, M.; Hussain, F.; Lee, J.-Y.; Shakoor, M.B.; Kwon, K.D. Groundwater status in Pakistan: A review of contamination, health risks, and potential needs. Crit. Rev. Environ. Sci. Technol. 2017, 47, 1713-1762. [CrossRef]

21. Ahmad, F. Detection of change in vegetation cover using multi-spectral and multi-temporal information for district Sargodha, Pakistan. Soc. Nat. 2012, 24, 557-571. [CrossRef]

22. Ahmad, A.; Senapati, S.; Khan, M.I.; Kumar, R.; Ramani, R.; Srinivas, V.; Sastry, M. Intracellular synthesis of gold nanoparticles by a novel alkalotolerant actinomycete, Rhodococcusspecies. Nanotechnology 2003, 14, 824-828. [CrossRef]

23. Ashraf, A.; Ahmad, Z.; Akhter, G. Monitoring Groundwater Flow Dynamics and Vulnerability to Climate Change in Chaj Doab, Indus Basin, Through Modeling Approach. In Springer Hydrogeology; Springer: Singapore, 2018; pp. $593-611$.

24. Boateng, T.K.; Opoku, F.; Acquaah, S.O.; Akoto, O. Groundwater quality assessment using statistical approach and water quality index in Ejisu-Juaben Municipality, Ghana. Environ. Earth Sci. 2016, 75, 489. [CrossRef] 
25. Ferroud, A.; Rafini, S.; Chesnaux, R. Using flow dimension sequences to interpret non-uniform aquifers with constant-rate pumping-tests: A review. J. Hydrol. X 2019, 2, 100003. [CrossRef]

26. Bozdağ, A. Combining AHP with GIS for assessment of irrigation water quality in Çumra irrigation district (Konya), Central Anatolia, Turkey. Environ. Earth Sci. 2015, 73, 8217-8236. [CrossRef]

27. Singh, S.; Raju, N.J.; Ramakrishna, C. Evaluation of Groundwater Quality and Its Suitability for Domestic and Irrigation Use in Parts of the Chandauli-Varanasi Region, Uttar Pradesh, India. J. Water Resour. Prot. 2015, 07, 572-587. [CrossRef]

28. Zhang, P.; Ward, P.; McMullen, L.M.; Yang, X. A case of 'blown pack'spoilage of vacuum-packaged pork likely associated with Clostridium estertheticum in Canada. Letters in applied microbiology. Lett. Appl. Microbiol. 2020, 70, 13-20. [CrossRef]

29. Boonkaewwan, S.; Sonthiphand, P.; Chotpantarat, S. Mechanisms of arsenic contamination associated with hydrochemical characteristics in coastal alluvial aquifers using multivariate statistical technique and hydrogeochemical modeling: A case study in Rayong province, eastern Thailand. Environ. Geochem. Health 2021, 43, 537-566. [CrossRef]

30. Rashid, A.; Ayub, M.; Javed, A.; Khan, S.; Gao, X.; Li, C.; Ullah, Z.; Sardar, T.; Muhammad, J.; Nazneen, S. Potentially harmful metals, and health risk evaluation in groundwater of Mardan, Pakistan: Application of geostatistical approach and geographic information system. Geosci. Front. 2021, 12, 101128. [CrossRef]

31. Rojas, J.P.; Arevalo, A.; Foulds, I.G.; Hussain, M.M. Design and characterization of ultra-stretchable monolithic silicon fabric. Appl. Phys. Lett. 2014, 105, 154101. [CrossRef]

32. Purushotham, D.; Prakash, M.R.; Rao, A.N. Groundwater depletion and quality deterioration due to environmental impacts in Maheshwaram watershed of R.R. district, AP (India). Environ. Earth Sci. 2010, 62, 1707-1721. [CrossRef]

33. Sujatha, D.; Reddy, B.R. Quality characterization of groundwater in the south-eastern part of the Ranga Reddy district, Andhra Pradesh, India. Environ. Earth Sci. 2003, 44, 579-586. [CrossRef]

34. Sunkari, E.D.; Abu, M.; Zango, M.S. Geochemical evolution and tracing of groundwater salinization using different ionic ratios, multivariate statistical and geochemical modeling approaches in a typical semi-arid basin. J. Contam. Hydrol. 2021, $236,103742$. [CrossRef]

35. Brown, G.W.; Birley, J.L.T.; Wing, J.K. Influence of Family Life on the Course of Schizophrenic Disorders: A Replication. Br. J. Psychiatry 1972, 121, 241-258. [CrossRef]

36. Odukoya, A.M. Geochemical and technology, Geochemical and quality assessment of groundwater in some Nigerian basement complex. Int. J. Environ. Sci. Technol. 2015, 12, 3643-3656. [CrossRef]

37. Karanth, K. Ground Water Assessment: Development and Management; Tata McGraw-Hill Education: Berkshire, UK, 1987.

38. Seth, R.; Mohan, M.; Singh, P.; Singh, R.; Dobhal, R.; Singh, K.P.; Gupta, S. Water quality evaluation of Himalayan Rivers of Kumaun region, Uttarakhand, India. Appl. Water Sci. 2014, 6, 137-147. [CrossRef]

39. Yahiaoui, R.; Tan, S.; Cong, L.; Singh, R.; Yan, F.; Zhang, W. Multispectral terahertz sensing with highly flexible ultrathin metamaterial absorber. J. Appl. Phys. 2015, 118, 083103. [CrossRef]

40. Brooks, N.; Adger, W.N.; Kelly, P.M. The determinants of vulnerability and adaptive capacity at the national level and the implications for adaptation. Glob. Environ. Change 2005, 15, 151-163. [CrossRef]

41. Szabolcs, I. The influence of irrigation water of high sodium carbonate content on soils. Agrokémia Talajt. 1964, 13, 237-246.

42. Tank, D.K.; Chandel, C.S.J.N. Analysis of the major ion constituents in groundwater of Jaipur city. Nat. Sci. $2010,8,1-7$.

43. World Health Organization. Guidelines for Drinking-Water Quality; World Health Organization: Geneva, Switzerland, 1993.

44. Dahiphale, P.; Kasal, Y.; Madane, D. Groundwater Potential Zones Identification Using Geographical Information System. Eur. J. Mol. Clin. Med. 2020, 7, 2741-2748.

45. Driessens, F.C.; Verbeeck, R. Biominerals; CRC Press: Boca Raton, FL, USA, 1990.

46. Balakrishnan, P. Groundwater quality mapping using geographic information system (GIS): A case study of Gulbarga City, Karnataka, India. Afr. J. Environ. Sci. Technol. 2011, 5, 1069-1084. [CrossRef]

47. Gu, X.; Xiao, Y.; Yin, S.; Hao, Q.; Liu, H.; Hao, Z.; Meng, G.; Pei, Q.; Yan, H. Hydrogeochemical Characterization and Quality Assessment of Groundwater in a Long-Term Reclaimed Water Irrigation Area, North China Plain. Water 2018, 10, 1209. [CrossRef]

48. Talpur, S.A.; Noonari, T.M.; Rashid, A.; Ahmed, A.; Baloch, M.Y.J.; Talpur, H.A.; Soomro, M.H. Hydrogeochemical signatures and suitability assessment of groundwater with elevated fluoride in unconfined aquifers Badin district, Sindh, Pakistan. SN Appl. Sci. 2020, 2, 1-15. [CrossRef]

49. WHO. Guidelines for Drinking-Water Quality; World Health Organization: Geneva, Switzerland, 2011; Volume 216, pp. 303-304.

50. Spitz, K.; Moreno, J. A Practical Guide to Groundwater and Solute Transport Modeling; John Wiley and Sons: Hoboken, NJ, USA, 1996.

51. Jehan, S.; Khan, S.; Khattak, S.A.; Muhammad, S.; Rashid, A.; Muhammad, N. Hydrochemical properties of drinking water and their sources apportionment of pollution in Bajaur agency, Pakistan. Measurement 2019, 139, 249-257. [CrossRef]

52. Prasanth, S.V.S.; Magesh, N.S.; Jitheshlal, K.V.; Chandrasekar, N.; Gangadhar, K. Evaluation of groundwater quality and its suitability for drinking and agricultural use in the coastal stretch of Alappuzha District, Kerala, India. Appl. Water Sci. 2012, 2, 165-175. [CrossRef]

53. Burkart, M.; Stoner, J. Nitrogen in Groundwater Associated with Agricultural Systems. In Nitrogen in the Environment; Elsevier: Amsterdam, The Netherlands, 2008; pp. 177-202.

54. Fordyce, F.M.; Vrana, K.; Zhovinsky, E.; Povoroznuk, V.; Toth, G.; Hope, B.C.; Iljinsky, U.; Baker, J. A health risk assessment for fluoride in Central Europe. Environ. Geochem. Health 2007, 29, 83-102. [CrossRef] 
55. Rashid, A.; Guan, D.-X.; Farooqi, A.; Khan, S.; Zahir, S.; Jehan, S.; Khattak, S.A.; Khan, M.S.; Khan, R. Fluoride prevalence in groundwater around a fluorite mining area in the flood plain of the River Swat, Pakistan. Sci. Total. Environ. 2018, 635, 203-215. [CrossRef]

56. Naseem, S.; Rafique, T.; Bashir, E.; Bhanger, M.I.; Laghari, A.; Usmani, T.H. Lithological influences on occurrence of high-fluoride groundwater in Nagar Parkar area, Thar Desert, Pakistan. Chemosphere 2010, 78, 1313-1321. [CrossRef]

57. Chen, J.; Huang, Q.; Lin, Y.; Fang, Y.; Qian, H.; Liu, R.; Ma, H. Hydrogeochemical Characteristics and Quality Assessment of Groundwater in an Irrigated Region, Northwest China. Water 2019, 11, 96. [CrossRef]

58. Subramani, T.; Rajmohan, N.; Elango, L. Groundwater geochemistry and identification of hydrogeochemical processes in a hard rock region, Southern India. Environ. Monit. Assess. 2009, 162, 123-137. [CrossRef] [PubMed]

59. Elango, L.; Kannan, R. Rock-water interaction and its control on chemical composition of groundwater. Dev. Environ. Sci. 2007, 5, 229-243.

60. Richter, D.D.; Markewitz, D.J.B. How deep is soil? BioScience 1995, 45, 600-609. [CrossRef]

61. Salem, Z.E.; Atwia, M.G.; El-Horiny, M. Hydrogeochemical analysis and evaluation of groundwater in the reclaimed small basin of Abu Mina, Egypt. Hydrogeol. J. 2015, 23, 1781-1797. [CrossRef]

62. Lawal, B.; Shittu, O.K.; Rotimi, A.A.; Olalekan, I.A.; Kamooru, A.A.; Ossai, P.C. Effect of Methanol Extract of Telfairia occcidentalis on Haematological Parameters in Wister Rats. J. Med. Sci. 2015, 15, 246-250. [CrossRef]

63. Meybeck, M. Global chemical weathering of surficial rocks estimated from river dissolved loads. Am. J. Sci. 1987, 287, 401-428. [CrossRef]

64. Zhang, J.; Zhou, J.; Zhou, Y.; Zeng, Y.; Ji, Y.; Sun, Y.; Lei, M. Hydrogeochemical characteristics and groundwater quality assessment in the plain area of Yarkant River Basin in Xinjiang, P.R. China. Environ. Sci. Pollut. Res. 2021, 1-13. [CrossRef]

65. Thin, P.P.; Hendrayana, H.; Wilopo, W.; Kawasaki, S. Assessment of groundwater facies in Wates Coastal Area, Kulon Progo, Yogyakarta, Indonesia. J. Degrad. Min. Lands Manag. 2018, 5, 1389-1401. [CrossRef]

66. Mao, X.; Jiang, R.; Xiao, W.; Yu, J. Use of surfactants for the remediation of contaminated soils: A review. J. Hazard. Mater. 2015, 285, 419-435. [CrossRef]

67. Chen, K.; Jiao, J.J.; Huang, J.; Huang, R. Multivariate statistical evaluation of trace elements in groundwater in a coastal area in Shenzhen, China. Environ. Pollut. 2007, 147, 771-780. [CrossRef]

68. Helena, B. Temporal evolution of groundwater composition in an alluvial aquifer (Pisuerga River, Spain) by principal component analysis. Water Res. 2000, 34, 807-816. [CrossRef]

69. Avvannavar, S.M.; Shrihari, S. Evaluation of water quality index for drinking purposes for river Netravathi, Mangalore, South India. Environ. Monit. Assess. 2007, 143, 279-290. [CrossRef]

70. Sahu, P.; Sikdar, P.K. Hydrochemical framework of the aquifer in and around East Kolkata Wetlands, West Bengal, India. Environ. Earth Sci. 2008, 55, 823-835. [CrossRef]

71. Bouderbala, A. Assessment of Groundwater Quality and its Suitability for Agricultural Uses in the Nador Plain, North of Algeria. Water Qual. Expo. Health 2015, 7, 445-457. [CrossRef] 